\title{
Homologous Recombination and Human Health: The Roles of BRCA1, BRCA2, and Associated Proteins
}

\author{
Rohit Prakash $^{1,3}$, Yu Zhang ${ }^{1,3}$, Weiran Feng ${ }^{1,2,3}$, and Maria Jasin ${ }^{1,2}$ \\ ${ }^{1}$ Developmental Biology Program, Memorial Sloan Kettering Cancer Center, New York, \\ New York 10065 \\ ${ }^{2}$ Louis V. Gerstner Jr. Graduate School of Biomedical Sciences, Memorial Sloan Kettering \\ Cancer Center, New York, New York 10065 \\ Correspondence: m-jasin@ski.mskcc.org
}

\begin{abstract}
Homologous recombination (HR) is a major pathway for the repair of DNA double-strand breaks in mammalian cells, the defining step of which is homologous strand exchange directed by the RAD51 protein. The physiological importance of HR is underscored by the observation of genomic instability in HR-deficient cells and, importantly, the association of cancer predisposition and developmental defects with mutations in HR genes. The tumor suppressors BRCA1 and BRCA2, key players at different stages of HR, are frequently mutated in familial breast and ovarian cancers. Other HR proteins, including PALB2 and RAD51 paralogs, have also been identified as tumor suppressors. This review summarizes recent findings on BRCA1, BRCA2, and associated proteins involved in human disease with an emphasis on their molecular roles and interactions.
\end{abstract}

Soon after homologous recombination (HR) Swas discovered to be an important DNA repair mechanism in mammalian cells, an association between HR deficiency and human disease was uncovered when the hereditary breast cancer suppressors BRCA1 and BRCA2 were found to be required for HR (Moynahan and Jasin 2010; King 2014). Subsequently, germline mutations in a number of other HR genes have been linked to tumor predisposition. Congenital defects have also been associated with impaired HR. Tumorigenesis can result from ongoing genomic instability from diminished repair, whereas developmental defects can arise from cell death/senescence. That HR genes act as genomic caretakers has generated widespread interest in both the scientific and medical communities. Because HR defects confer sensitivity to certain DNA-damaging agents, they are being exploited in cancer therapies. Drugs that cause synthetic lethality in the context of HR defects also hold promise for treatment (Bryant et al. 2005; Farmer et al. 2005). This review provides a brief overview of HR in mammalian cells and summarizes the molecular roles of BRCA1, BRCA2, and associated HR proteins involved in human disease. Extensive discussion of HR pathways can be found in Mehta and Haber (2014).

${ }^{3}$ These authors contributed equally to this article.

Editors: Stephen Kowalczykowski, Neil Hunter, and Wolf-Dietrich Heyer

Additional Perspectives on DNA Recombination available at www.cshperspectives.org

Copyright (C) 2015 Cold Spring Harbor Laboratory Press; all rights reserved; doi: 10.1101/cshperspect.a016600

Cite this article as Cold Spring Harb Perspect Biol 2015;7:a016600 
R. Prakash et al.

\section{THE IMPORTANCE OF HR IN MAMMALIAN CELLS}

DNA lesions, such as double-strand breaks (DSBs), threaten the integrity of the genome, but HR provides a mechanism to precisely repair the damage. DSBs repaired by HR are first end resected to generate $3^{\prime}$ single-stranded DNA (ssDNA) (Fig. 1) (see Symington 2014). A DNA strand-exchange protein-RAD51 in mammalian cells-binds to the ssDNA to form a nucleoprotein filament, which promotes strand invasion into a homologous duplex to initiate repair synthesis (see Morrical 2015). In the synthesisdependent strand-annealing (SDSA) pathway of $\mathrm{HR}$, the newly synthesized DNA dissociates to anneal to the other DNA end, and the HR event is completed by ligation (see Zelensky et al. 2014 and Daley et al. 2014). More complex pathways involve Holliday junction resolution or dissolution (Jasin and Rothstein 2013; see also Bizard and Hickson 2014; Wyatt and West 2014). DSB repair can also occur by a second major mechanism, nonhomologous end joining (NHEJ) (Chapman et al. 2012b). NHEJ differs from HR in that the DNA ends are protected from resection before being rejoined; nevertheless, deletions and insertions can arise during NHEJ. The preferred template for HR is the identical sister chromatid, although the homolog can be used at lower frequency (Johnson and Jasin 2001). The use of the sister chromatid leads to precise repair, restoring the original sequence that was present before damage, but it is limited

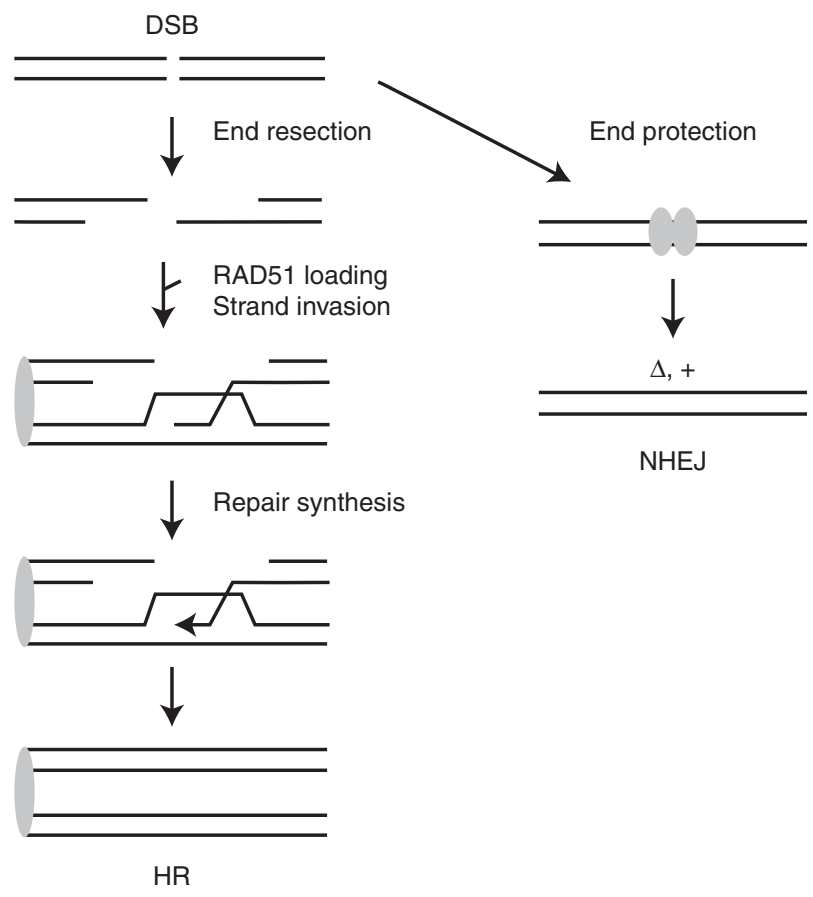

Figure 1. Simplified schemes of double-strand break (DSB) repair by homologous recombination (HR) and nonhomologous end joining (NHEJ). Once a DSB is generated, it can be processed for HR by end resection proteins, leading to ssDNA. The RAD51 strand-exchange protein forms a nucleoprotein filament with ssDNA that invades an unbroken homologous DNA, typically the sister chromatid, as shown. The $3^{\prime}$ end primes DNA synthesis from the homologous DNA; using the sister chromatid, the repair can be precise to restore the original sequence before damage. To complete HR, the newly synthesized strand can dissociate to anneal to the other end. Other outcomes are also possible, for example, in which Holliday junctions are formed and either dissolved or resolved. Alternatively, DNA ends are protected from end resection by NHEJ proteins; subsequent steps in NHEJ can result in mutagenic repair with deletions and insertions $(\Delta,+)$. 
to the $S / G_{2}$ phases of the cell cycle, whereas NHEJ is operational throughout the cell cycle (Rothkamm et al. 2003).

Although HR has long been known to be a major DNA repair mechanism in bacteria and yeast (see Mehta and Haber 2014; Reams and Roth 2015), the importance of HR in the maintenance of mammalian genome integrity has only emerged in the last two decades. Direct evidence came from molecular analysis of DSB repair, in which HR and NHEJ are both found to be robust repair mechanisms (Fig. 1) (Rouet et al. 1994; Liang et al. 1998; Johnson and Jasin 2000). This finding forms the basis of current genome-editing approaches in mammalian cells (Cong et al. 2013; Mali et al. 2013).

Strong genetic evidence for the importance of HR comes from the study of mice deficient in the RAD51 strand-exchange protein. Rad51 disruption is lethal early in embryogenesis and Rad51 null cells cannot be propagated (Lim and Hasty 1996; Tsuzuki et al. 1996). The lethality is attributed to the impaired repair of lesions that arise during DNA replication in the rapidly cycling cells of the embryo. Thus, a critical function of HR is likely to be the repair of replication-associated damage (see Syeda et al. 2014), as is the case in bacteria (Cox et al. 2000). HR is also critical for the repair of interstrand crosslinks (Long et al. 2011).

HR and NHEJ can "compete" for the repair of the same lesion but also "collaborate" in the repair of distinct lesions (Fig. 2A) (Kass and Jasin 2010). Competition is evidenced in a standard HR reporter assay in which a DSB is induced by the I-SceI endonuclease: HR, measured as $\mathrm{GFP}^{+}$cells, is elevated in NHEJ mutant cell lines relative to wild-type cells (Fig. 2B)

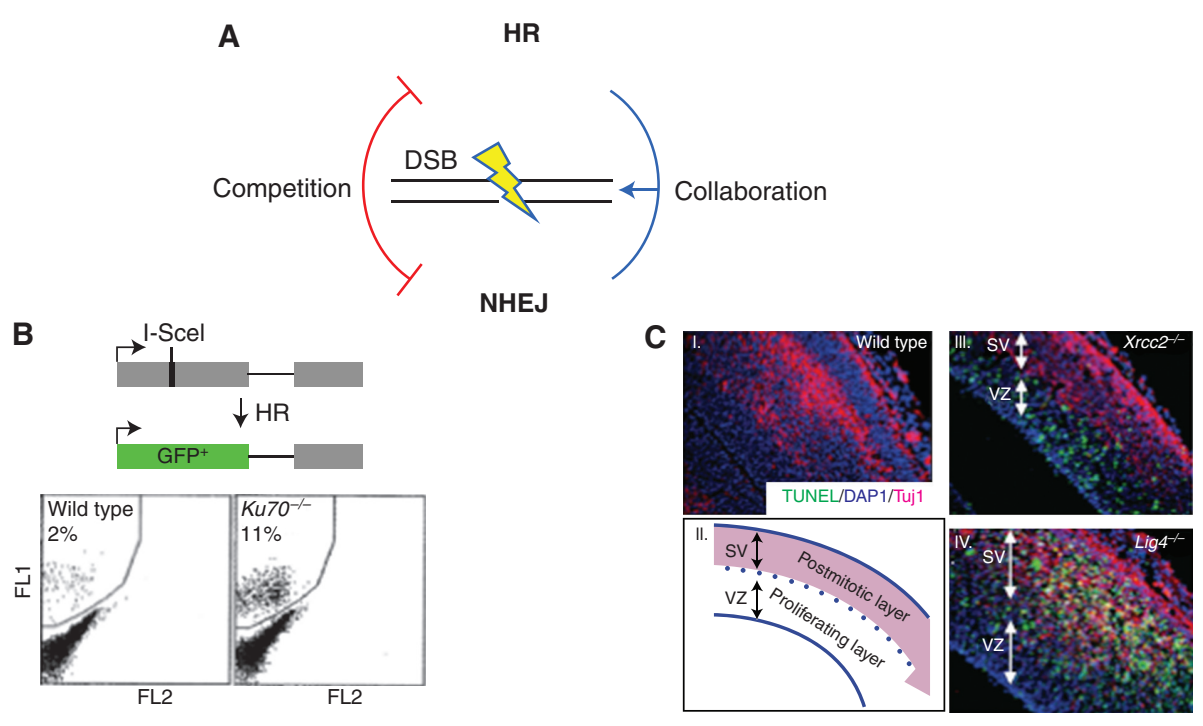

Figure 2. Competition and collaboration between double-strand break (DSB) repair pathways. (A) Schematic of the interactions between the homologous recombination (HR) and nonhomologous end joining (NHEJ) pathways for DSB repair. (B) Competition for repair of a DSB. In the direct repeat green fluorescent protein (DR-GFP) reporter assay, a DSB repaired through HR restores a functional GFP gene, as detected by flow cytometry. NHEJ-deficient $K u 70^{-/-}$cells show substantially elevated HR, showing how HR and NHEJ can act on the same DSB, such that NHEJ suppresses HR (modified from Pierce et al. 2001). The DSB is generated by I-SceI endonuclease. $(C)$ Collaboration between HR and NHEJ, as illustrated in the embryonic brain. $(i, i i)$ Apoptosis is rare in the wild-type embryonic brain (E13.5), as indicated by the lack of TdT-mediated dUTPbiotin nick end labeling (TUNEL) staining in either the proliferating ventricular zone (VZ) or the postmitotic subventricular (SV) zone (marked with Tuj1). (iii) HR-deficient $X r c c 2^{-/-}$cells show substantial apoptosis in the VZ. (iv) In contrast, NHEJ-deficient Lig $4^{-/}$cells predominantly have elevated apoptosis in the SV. Therefore, HR and NHEJ both contribute to the integrity of the embryonic brain (modified from Orii et al. 2006). 
R. Prakash et al.

(Pierce et al. 2001). The rescue of certain HR mutants with combined NHEJ deficiency also speaks to the competition between pathways (see below) (Bouwman et al. 2010; Bunting et al. 2010). Collaboration between HR and NHEJ is illustrated in the different cell layers of the embryonic brain. $\mathrm{HR}$ is required in the proliferating cell layer and NHEJ is required in the postmitotic cell layer, such that mutation of either an HR or NHEJ pathway component leads to high levels of apoptosis but in a distinct cell layer (Fig. 2C) (Orii et al. 2006). Collaboration between pathways is also observed in some HR/NHEJ double mutant mice, which show more severe phenotypes than either single mutant (Couedel et al. 2004; Mills et al. 2004). HR and NHEJ can even be used to repair the same lesion through a break-induced replicationtype event, which is initiated by HR and completed by NHEJ (Richardson and Jasin 2000). Special cases are the programmed DSBs, which are channeled into defined repair pathways, for example, HR for SPO11-generated DSBs during meiosis (see Lam and Keeney 2015) and NHEJ for RAG-induced DSBs in the immune system (Chapman et al. 2012b).

Early studies of mammalian homologs of yeast HR genes did not link HR to tumor suppression. Mouse knockouts showed embryonic lethality (Rad51, Lim and Hasty 1996; Tsuzuki et al. 1996) or, at the other extreme, little or no phenotype (Rad52, Rijkers et al. 1998; Rad54, Essers et al. 1997). However, characterization of BRCA1 and BRCA2 led to the discovery of the link between HR and human health, in particular, tumor suppression (Moynahan and Jasin 2010). Subsequent work has implicated a number of other HR proteins, including PALB2 and the RAD51 paralogs.

\section{BRCA1}

\section{BRCA1 Mutations in Patients}

Breast cancer early onset gene 1 (BRCA1) was identified in the early 1990s as one of the major hereditary breast cancer susceptibility genes (Futreal et al. 1994; Miki et al. 1994; King 2014). Germline mutations in BRCA1 confer a high lifetime risk for breast $(\geq 60 \%)$ and ovar- ian $(\geq 40 \%)$ cancer (average cumulative risks by age 70 ), as well as a lesser increase in risk for pancreatic, prostate, and other cancers (King et al. 2003; Metcalfe et al. 2010). Mutation carriers are heterozygous, whereas tumors often show loss of the wild-type allele (see below) (Futreal et al. 1994). BRCA1-mutated breast cancers are typically basal-like rather than luminal, and negative for estrogen and progesterone receptors and human epidermal growth factor receptor 2 (HER2) amplification (i.e., "triple negative"); thus, they do not respond to hormonal therapies or therapies that target HER2, making them particularly difficult to treat (Foulkes et al. 2003).

BRCA1 mutant allele frequencies are sufficiently high that individuals with biallelic mutations could be expected in the population; however, until recently, only one individual with bona fide deleterious mutations in both $B R C A 1$ alleles has thus far been reported (Domchek et al. 2013), consistent with the embryonic lethality associated with BRCA1 loss in mice (Moynahan 2002). This individual likely survived to adulthood because one of her BRCA1 alleles is hypomorphic. However, she had developmental issues, early onset ovarian cancer, and toxicity from carboplatin and paclitaxel therapy (Domchek et al. 2013). The identification of an individual with biallelic BRCA1 mutations has important implications because the combination of congenital issues, cancer, and sensitivity to interstrand cross-linking agents like platinum-based drugs is associated with a broadly defined syndrome called Fanconi anemia (D’Andrea 2013). More recently, a second individual with biallelic BRCA1 mutations has been identified, in this case, with breast cancer as well as congenital abnormalities (Sawyer et al. 2015). Thus, biallelic mutations in BRCA1 are now considered to cause a distinct subtype of Fanconi anemia (FA-S).

\section{BRCA1 Domains and Interactions}

Human BRCA1 encodes an 1863 amino acid protein that can be divided into three regions, the amino terminal Really Interesting New Gene (RING) domain, a central part with a large un- 

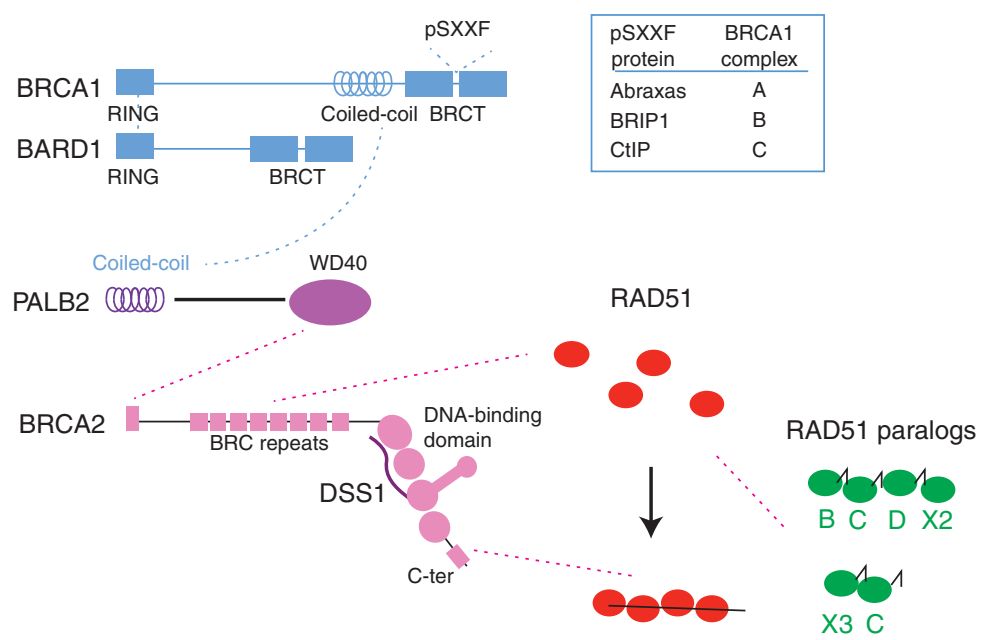

Figure 3. Protein interactions for a functional homologous recombination (HR) pathway. BRCA1 executes its various functions using the RING, coiled-coil, and BRCT domains. BRCA1 and BARD1 interact at their respective RING domains. BRCA1 BRCT motif mediates interaction through a pSXXF motif in Abraxas, BRIP1, and CtIP in the A, B, and C complexes, respectively. The coiled-coil domain of BRCA1 recognizes the coiled-coil domain of PALB2, which, in turn, binds BRCA2 through its WD40 domain. BRCA2 has mediator activity for loading RAD51 onto replication protein A (RPA)-coated ssDNA (BRC repeats) and for the stabilization of the RAD51 presynaptic filament carboxy terminal (C-ter) domain. RAD51 paralog complexes also interact with RAD51 and may promote/stabilize RAD51 filaments. BRCA2 also has a DSS1 and DNA-binding domain that, although not required for HR, likely is required for optimal HR levels. This domain consists of four globular domains and a helical tower domain with a three-helix bundle at its apex.

structured region encoded by exon 11 followed by a coiled-coil domain, and tandem BRCA1 carboxy-terminal repeats (BRCTs) (Fig. 3) (Li and Greenberg 2012). Through these domains, BRCA1 forms complexes with several proteins, implicating BRCA1 in multiple cellular functions, such as transcription regulation, cell-cycle checkpoint activation, and DNA repair (Venkitaraman 2014). Importantly, the role of BRCA1 in DNA repair, in particular in HR repair (Moynahan et al. 1999), has thus far been one of its most well-recognized functions thought to be critical for its tumor suppressor activity.

\section{RING Domain Interactions with BARD1}

BRCA1 forms a heterodimer with BARD1, another RING and BRCT-containing protein, through helices flanking the core RING motif (Fig. 3) (Wu et al. 1996; Brzovic et al. 2001). BARD1 appears to be an obligate partner of BRCA1 because BRCA1-BARD1 interaction is essential for their mutual stability in vivo, and
Brcal and Bard1 knockout mice show identical phenotypes (McCarthy et al. 2003; Shakya et al. 2008). Although not nearly as prevalent as $B R C A 1$ mutations, germline BARD1 mutations have also been reported in breast and ovarian cancer families (De Brakeleer et al. 2010; Sabatier et al. 2010; Ratajska et al. 2012).

As a RING domain is a common protein structure for E3 ubiquitin ligases, the E3 ligase activity of the BRCA1-BARD1 heterodimer has been a focus of interest. BRCA1-BARD1 can direct both mono- and polyubiquitylation depending on the E2 conjugating enzyme (Christensen et al. 2007). In addition to more standard linkages, BRCA1-BARD1 catalyzes the formation of noncanonical lysine ${ }^{6}$-linked ubiquitin chains (K6-polyUb), which likely serve as a signal for complex assembly and/or protein stabilization rather than degradation (Wu-Baer et al. 2003; Nishikawa et al. 2004). In vivo, BRCA1BARD1 appears to play a critical role in the accumulation of K6-polyUb conjugates at DSBs (Morris and Solomon 2004). Substrates 
for BRCA1-BARD1-mediated polyubiquitylation include BRCA1 itself and the end resection factor CtIP (Yu et al. 2006), and, for monoubiquitylation, include histone $\mathrm{H} 2 \mathrm{~A}$, which has been implicated in the maintenance of silenced heterochromatin (Zhu et al. 2011).

The in vivo significance of the BRCA1 E3 ligase activity to tumor suppression has been challenged by recent reports showing that the BARD1-interaction-proficient but E3 ligasedeficient BRCA1 I26A mouse mutant is competent for HR and is not tumor prone (Reid et al. 2008; Shakya et al. 2011). In contrast, the cancer-associated C61G RING domain mutant, which disrupts the interaction with BARD1 rather than specifically impairing interaction with E2 enzymes, causes tumor susceptibility in mice as well as in patients (Wu et al. 1996; Drost et al. 2011). Another deleterious mutant, BRCA1 C64R, also has impaired interaction with BARD1 (Caleca et al. 2014). Thus, whereas the integrity of the BRCA1 RING domain region is critical for tumor suppression, apparently because of its interaction with BARD1, the physiological role of the E3 ligase activity itself is uncertain. One possibility is that autoubiquitylation of BRCA1 increases its stability because the BRCA1 I26A mutant protein is present at lower levels in cells (Reid et al. 2008). These cells have elevated DNA-damage-induced genomic instability, suggesting the possibility that wild-type levels of BRCA1 are required for maintenance of genomic integrity.

\section{Coiled-Coil Domain Interaction with PALB2}

Through its coiled-coil domain, BRCA1 interacts with the bridging protein PALB2, which connects BRCA1 with the other major hereditary breast cancer suppressor BRCA2 (Fig. 3) (Xia et al. 2006; Sy et al. 2009; Zhang et al. 2009a,b). BRCA1-PALB2-BRCA2 interaction plays an important role in RAD51 cellular dynamics and will be discussed further below.

\section{BRCT Interactions with Several Proteins}

The BRCT repeats mediate interactions between BRCA1 and several proteins involved in the
DNA-damage response, including Abraxas/ FAM175A, BRIP1/BACH1, and CtIP/RBBP8, which are part of the BRCA1-A, -B, -C complexes, respectively (Moynahan and Jasin 2010; Li and Greenberg 2012). The BRCA1 BRCTrepeats recognize a phosphorylated serine in a pSXXF motif (Yu et al. 2003b), which exists in each of Abraxas, BRIP1, and CtIP (Fig. 3). Importantly, BRCT repeats on one BRCA1 molecule can be occupied by only one pSXXF motif, implying the mutually exclusive composition of the BRCA1-A, -B, and -C complexes. The importance of the interaction between BRCA1 and phosphorylated proteins at the BRCT repeats is emphasized by the findings that disruption of this interaction is associated with tumor susceptibility in mice and humans as well as with reduced HR (Shakya et al. 2011). A challenge is to determine which of the multiple protein interactions is/are critical for tumor suppression.

The BRCA1-A complex targets BRCA1 to ubiquitin conjugates at DSBs, which are critical for DNA-damage signaling and repair (Huen et al. 2007; Doil et al. 2009). Deficiency of UBC13, the E2 enzyme required for these ubiquitin conjugates, causes severe defects in DNAdamage signaling and HR (Wang and Elledge 2007; Zhao et al. 2007). In addition to BRCA1, Abraxas binds to another component of the BRCA1-A complex RAP80, which recognizes polyubiquitylated histones like $\mathrm{H} 2 \mathrm{AX}$ to recruit the BRCA1-A complex to DNA-damage sites (Kim et al. 2007; Sobhian et al. 2007; Wang et al. 2007). The BRCA1-A complex consists of other proteins with ubiquitin-binding domains and also with deubiquitylation activity, which can provide complex regulation of protein dynamics at damage sites (Huen et al. 2010). Notably, BRCA1-A and -C complexes appear to have opposite roles in an early step of HR, DNA end resection (discussed below).

The BRIP1 component of the BRCA1-B complex is a helicase that unwinds secondary DNA structures, such as four-stranded structures (G4 DNA), which may impede DNA replication (Cantor et al. 2004; London et al. 2008; Wu et al. 2008). BRCA1 recruits phosphorylated BRIP1 to chromatin during $S$ phase, 
HR Proteins Linked to Human Disease

and the BRCA1-B complex is required for S-phase checkpoint activation when replication forks are stalled or collapsed (Cantor et al. 2001; Litman et al. 2005; Greenberg et al. 2006). Biallelic BRIP1 mutations, which cause cellular sensitivity to cross-linking agents, have been identified in patients with developmental issues and cancer predisposition, such that BRIP1 is considered to be a Fanconi anemia gene subtype (FA-J); monoallelic mutations are associated with breast and ovarian cancer predisposition (Cantor et al. 2001; Levitus et al. 2005; Levran et al. 2005; Litman et al. 2005; Seal et al. 2006; Rafnar et al. 2011).

\section{BRCA1 Function in HR}

A link between BRCA1 and RAD51 came from the observation of their subcellular colocalization in nuclear foci (Scully et al. 1997). An essential role for BRCA1 in HR was established by the direct demonstration of substantially reduced HR in BRCA1 mutant cells (Moynahan et al. 1999, 2001a). These studies further showed that BRCA1 mutant cells follow the paradigm of other HR mutant mammalian cells identified around the same time, in terms of having spontaneous chromosome instability and high sensitivity to cross-linking agents (Moynahan et al. 2001a). Multiple breast cancer and engineered mutations in BRCA1 have been shown to confer defects in HR, connecting the HR and cancer suppressor roles of BRCA1 (Ruffner et al. 2001; Sy et al. 2009; Drost et al. 2011; Towler et al. 2013). BARD1 has also been shown to be important for HR (Westermark et al. 2003; Laufer et al. 2007). BRCA1-deficient cells are exquisitely sensitive to inhibitors of poly(ADP-ribose) polymerases (PARP) (Bryant et al. 2005; Farmer et al. 2005; McCabe et al. 2006), which function in DNA single-strand break repair. Synthetic lethality between PARP inhibition and HR deficiency is currently being explored as an approach to cancer therapy.

The molecular mechanism by which BRCA1 contributes to HR has been extensively studied in the past decade. Compelling evidence suggests that BRCA1 functions in two distinct steps: (1) $5^{\prime}$ to $3^{\prime}$ resection of DSBs to generate $3^{\prime}$ ssDNA overhangs, and (2) loading of the RAD51 recombinase onto the ssDNA.

\section{BRCA1 and End Resection}

The involvement in resection was first suggested by the observation that BRCA1 mutant cells are defective in a second homology-based DSB repair pathway, single-strand annealing (SSA), which, like $\mathrm{HR}$, relies on a resection intermediate but diverges at later steps (Fig. 4) (Stark et al. 2004). End resection is a key step in DSB repair pathway choice, promoting pathways that use homology while suppressing canonical NHEJ (Kass and Jasin 2010). Consistent with a role in resection, BRCA1 colocalizes with the resection complex MRE11-RAD50-NBS1 (MRN) after DNA damage and directly interacts with the resection factor CtIP (Wong et al. 1998; Yu et al. 1998; Zhong et al. 1999; Sartori et al. 2007).

One model is that BRCA1 interacts with phosphorylated CtIP (BRCA1-C complex) through its carboxy-terminal BRCT domain to cooperate with the MRN nuclease to catalyze resection (Wong et al. 1998; Yu et al. 1998; Sartori et al. 2007; Chen et al. 2008). As CDK-dependent phosphorylation of CtIP is required for CtIP activation and BRCA1-CtIP interaction, it has been proposed that BRCA1 promotes resection by recruiting CDK-phosphorylated/activated CtIP to DSB sites (Yu et al. 2003b; Yu and Chen 2004; Yun and Hiom 2009; Buis et al. 2012). Surprisingly, however, a CtIP mouse mutant defective for BRCA1 interaction has recently been reported to support HR to a similar extent as wild-type CtIP (Reczek et al. 2013), questioning the biological significance of the BRCA1-phospho-CtIP interaction. Possibly, other proteins target CtIP to damage sites (Daugaard et al. 2012).

In addition to specifically promoting resection, BRCA1 also appears to act as an antagonizer of the resection suppressor 53BP1 (Fig. 4) (Bouwman et al. 2010; Bunting et al. 2010). In the absence of BRCA1, 53BP1 accumulates at DSBs to block resection and HR, ultimately leading to chromosomal aberrations and cell death; deletion of 53BP1, however, rescues the viability of BRCA1 mutant cells and mice, as 
R. Prakash et al.

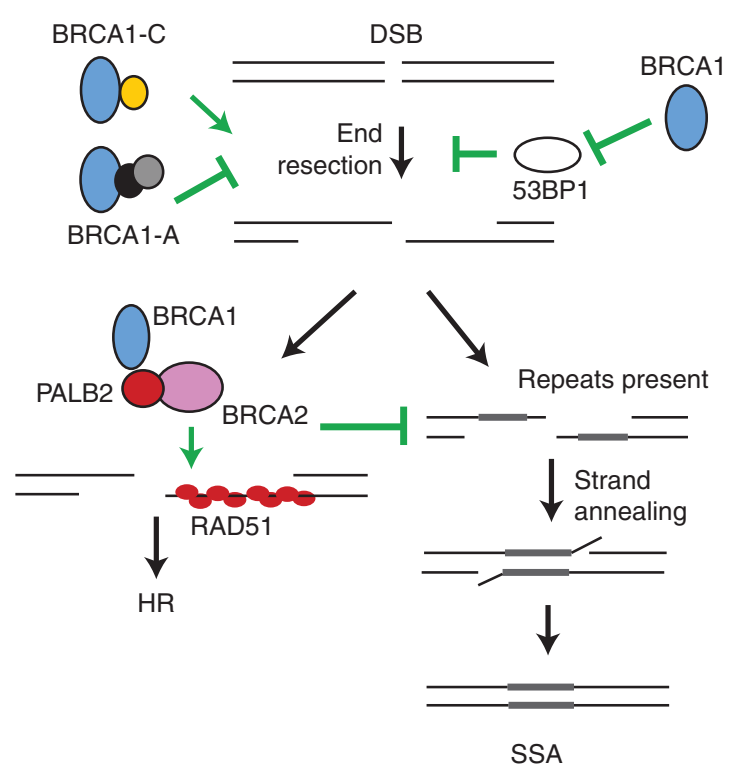

Figure 4. BRCA1 and BRCA2 have distinct roles in HR. BRCA1 acts at an early HR step to promote end resection and at a later step to recruit PALB2 and, hence, promote BRCA2 chromatin localization. BRCA1 acts by antagonizing the resection inhibitor 53BP1. It may further regulate resection by recruiting CtIP (gold ball) in the BRCA1-C complex, while inhibiting end resection in the BRCA1-A complex containing Abraxas and RAP80 (black and gray balls); alternatively, Abraxas-RAP80 may act independently of BRCA1 to suppress resection. BRCA2 promotes loading of RAD51 recombinase onto the resection product to form an RAD51-ssDNA filament, which is essential for HR and prevents the engagement of the $3^{\prime}$-ssDNA into the deleterious single-strand annealing (SSA) pathway. SSA acts when homologous repeats are present and leads to a deletion of sequences between the repeats.

well as the HR defects of BRCA1-deficient cells. Analysis of BRCA1 and 53BP1 in DNA-damage-induced foci by superresolution microscopy suggests that BRCA1 spatially excludes 53BP1 from the proximity of DSBs during $S$ phase (Chapman et al. 2012a).

As CtIP-dependent resection is proficient with the combined absence of BRCA1 and 53BP1 (Bunting et al. 2010), it appears that the role of BRCA1 in relieving 53BP1 is upstream of recruiting CtIP at DSBs. The balance between BRCA1 and 53BP1 at DSBs has been shown to be regulated by acetylation of histone H4K20me2, which interferes with 53BP1 binding (Tang et al. 2013) and also involves RIF1, which binds ATM-phosphorylated 53BP1 (Chapman et al. 2013; Escribano-Diaz et al. 2013; Feng et al. 2013; Zimmermann et al. 2013). The BRCA1-RIF1 antagonism in human cells has been reported to involve BRCA1 interaction with phosphorylated CtIP (Escribano-
Diaz et al. 2013), although it is uncertain as yet how to reconcile this finding with the lack of an HR phenotype in the phosphor-CtIP mutant mouse cells (Reczek et al. 2013).

Surprisingly, an antiresection activity of BRCA1-A complex members has also been reported (Fig. 4). Depleting members like RAP80 results in a hyperrecombination phenotype associated with increased CtIP-dependent resection (Coleman and Greenberg 2011; Dever et al. 2011; Hu et al. 2011; Kakarougkas et al. 2013). The RAP80 subunit of the BRCA1-A complex has been suggested to inhibit resection by binding to ubiquitin chains at DSBs (Biswas et al. 2011; Coleman and Greenberg 2011); its inhibitory effect can be relieved by the deubiquitylating factor POH1 (Kakarougkas et al. 2013). Based on the mutual exclusiveness of the BRCA1 complexes, a model has been proposed to explain this observation, in which the absence of the BRCA1-A complex allows more 
BRCA1 to functionally interact in other complexes that promote resection (Coleman and Greenberg 2011; Hu et al. 2011). Physiologically, the promotion and inhibition of end resection by different complexes can act to fine tune the response. The opposing roles of BRCA1 complexes may help to explain the different degrees of resection defects upon BRCA1 disruption reported in the literature (Chen et al. 2008; Kakarougkas et al. 2013; Zhou et al. 2013).

\section{BRCA1 and RAD51 Loading}

In addition to its role in end resection, BRCA1 appears to have a downstream role in HR by promoting the localization of downstream HR factors (Fig. 4). Resected DNA is a substrate for RAD51 binding, but it is initially bound by the ssDNA-binding replication protein A (RPA), requiring mediator proteins like BRCA2 to assist RAD51 loading onto ssDNA concomitant with RPA eviction (see Zelensky et al. 2014). BRCA1 promotes the recruitment of BRCA2 to DSBs through the bridging protein PALB2 (Fig. 3) (Xia et al. 2006; Sy et al. 2009; Zhang et al. 2009a,b). The anchor role of BRCA1 is indicated by the hierarchy of the DNA-damageinduced focus formation: BRCA1 disruption diminishes PALB2, BRCA2, and RAD51 foci; PALB2 disruption reduces BRCA2 and RAD51 foci but not BRCA1 foci; BRCA2 disruption only impairs RAD51 foci. Consistent with the idea that BRCA1 facilitates RAD51-dependent HR through PALB2, clinical BRCA1 mutations, which abrogate BRCA1-PALB2 interactions, cause HR defects. The role of BRCA1 in RAD51 loading appears to be dispensable when 53BP1 is absent, at least in mouse cells, however, as eliminating 53BP1 rescues the HR deficiency of BRCA1 null cells (Bouwman et al. 2010; Bunting et al. 2010,2012). It seems possible that 53BP1 loss creates a favorable condition for RAD51 loading (e.g., creating hyperresected ends), which bypasses a downstream role for BRCA1 in HR.

The BRCA1 coiled-coil domain, which binds PALB2, is distinct from the BRCT domain (Fig. 3). However, mutations in the BRCT domain often result in destabilization of the mu- tant BRCA1 protein (Williams and Glover 2003; Williams et al. 2003; Lee et al. 2010) and thus impair RAD51 loading despite an intact PALB2interaction domain (Johnson et al. 2013). Interestingly, therapy-resistant human breast cancer cells have been isolated in which HSP90 stabilization of the mutant BRCA1 protein, combined with reduced 53BP1 levels, restores RAD51 focus formation (Johnson et al. 2013). These results emphasize the complexity of acquired resistance involving BRCA1.

\section{BRCA2}

\section{BRCA2 Mutations in Patients}

$B R C A 2$ is the second major hereditary breast cancer susceptibility gene (Wooster et al. 1995; Tavtigian et al. 1996). BRCA2 breast cancers are distinct from those with BRCA1 mutations in that they are generally of the luminal subtype, rather than basal-like, and so are often estrogen-receptor positive (Jonsson et al. 2010; Waddell et al. 2010). The difference in breast cancer type may be related to the observation that BRCA1 mutations alter mammary progenitor cell fate commitment (see Proia et al. 2011, and references therein). Like $B R C A 1, B R C A 2$ mutation carriers are also predisposed to ovarian cancer as well as other tumors at a lower penetrance, such as that of the prostate and pancreas (Ozcelik et al. 1997; Consortium 1999; Antoniou et al. 2003; Edwards et al. 2003; King et al. 2003; van Asperen et al. 2005). Deleterious $B R C A 2$ mutations, as with BRCA1, have been reported throughout the length of the protein, mostly truncating mutations but also point mutations (Breast Cancer Information Core, research.nhgri.nih.gov/bic/). Mutations of uncertain clinical significance have also been identified such that several approaches have been devised to evaluate their functional significance (Hucl et al. 2008; Kuznetsov et al. 2008; Chang et al. 2009; Biswas et al. 2011, 2012; Bouwman et al. 2013). These and other approaches have also been used to evaluate the importance of rationally designed mutations.

Tumors from $B R C A 2$ mutation carriers were initially reported to have lost the wild-type $B R C A 2$ allele in most cases (Collins et al. 1995; 
R. Prakash et al.

Gudmundsson et al. 1995). However, these findings were recently questioned by a study showing that BRCA1 or BRCA2 loss of heterozygosity (LOH) does not always occur in breast tumors, and, when it does occur, LOH can involve the mutant rather than the wild-type $B R C A$ allele (King et al. 2007). In the mouse, germline Brca2 heterozygous mutation promotes tumor formation in a Kras-driven mouse pancreatic cancer model, and loss of wild-type Brca2 allele is not observed in some tumors (Skoulidis et al. 2010). These studies open the possibility of haploinsufficiency of BRCA genes, although the different approaches used in these studies and epigenetic silencing of the remaining wild-type allele could potentially account for some of the observations.

Patients with biallelic BRCA2 mutations are classified as having a Fanconi anemia subtype (FA-D1), which is associated with brain, kidney, and hematological tumor types very early in life as well as with developmental issues (Howlett et al. 2002; Meyer et al. 2014). In these cases, at least one of the BRCA2 alleles is expected to be hypomorphic, given the requirement of Brca2 during embryogenesis in mice (Moynahan 2002).

\section{BRCA2 Domains and Interactions}

Human BRCA2 is a 3418 amino acid protein, which consists of multiple domains (Fig. 3). In addition to binding PALB2 (discussed below), BRCA2 binds RAD51 at motifs repeated in the middle of the protein (BRC repeats) and at a distinct domain in the carboxyl terminus (Sharan et al. 1997; Wong et al. 1997). In addition, BRCA2 binds DNA and the DSS1 protein at a conserved region following the BRC repeats (Yang et al. 2002).

\section{RAD51: Binding at the BRC Repeats and Carboxyl Terminus}

Mammalian BRCA2 has eight BRC repeats, which are conserved among vertebrates in both sequence and spacing, but not in the intervening sequences (Bignell et al. 1997). BRC repeats appear to regulate RAD51 filament for- mation in a complex manner. An individual BRC peptide, when present in excess, disrupts RAD51 filament formation in vitro (Davies et al. 2001) and interferes with damage-induced RAD51 foci formation and HR in vivo (Chen et al. 1999; Xia et al. 2001; Stark et al. 2002; Saeki et al. 2006), presumably by mimicking the interface between RAD51 monomers within the RAD51 filament (Pellegrini et al. 2002). In contrast, the full-length BRCA2 protein or the peptide containing all eight $\mathrm{BRC}$ repeats promotes RAD51-mediated strand exchange by stimulating assembly of RAD51 onto ssDNA, while preventing nucleation of RAD51 on dsDNA (Carreira et al. 2009; Jensen et al. 2010; Liu et al. 2010; Thorslund et al. 2010). Even a single BRC4 motif has been shown to exhibit these activities under the appropriate experimental conditions (Carreira et al. 2009). The underlying mechanism is thought to be through blocking RAD51-mediated ATP hydrolysis and, thus, stabilizing the active ATP-bound RAD51-ssDNA filament. Evidence from Rad51 mutant chicken cells indicates that Rad51 is sequestrated under normal conditions by interaction with the BRC repeats, but in response to damage, this sequestered fraction undergoes mobilization, suggesting dynamic regulation of Rad51 through interaction with the BRC repeat region (Yu et al. 2003a).

Genetic studies further established the importance of BRC repeats for BRCA2 function. Mice deleted for the BRC-encoding exon 11 in the germline are inviable, whereas somatic exon 11 deletion causes tumor development (Jonkers et al. 2001). Conversely, a mouse mutant that maintains the amino terminus of BRCA2 including just three BRC repeats can survive embryogenesis, albeit at low frequency (Friedman et al. 1998). On the cellular level, the essentiality of BRC repeats for BRCA2 function is supported by proliferation defects observed in exon 11-deleted embryonic fibroblasts (Bouwman et al. 2010) and the failure to rescue defects in BRCA2-deficient cells with constructs devoid of BRC repeats (Chen et al. 1998b). Point mutations in BRC repeats that impair RAD51 interaction are found in breast cancer patients (Pellegrini et al. 2002), although functional studies 
are required to determine the effects of these mutations in full-length BRCA2.

Both functional redundancy and divergence may exist among BRC repeats in the context of full-length BRCA2 protein. Redundancy among $\mathrm{BRC}$ repeats is supported by the sufficiency of an individual BRC repeat for HR function within the BRC-RPA fusion protein (see below; Saeki et al. 2006). A divergence of function is suggested by the poor sequence identity between BRC repeats within a species, in contrast to high interspecies conservation of individual repeats (Bignell et al. 1997). Consistent with this notion, electron microscopy shows that different BRC repeats bind to different regions of RAD51 in filaments (Galkin et al. 2005). Biochemical studies led to the proposal of the existence of two classes of $\mathrm{BRC}$ repeats: $\mathrm{BRC1}, 2,3$, and 4 bind to RAD51 monomers at high affinity and reduce the ATPase activity of RAD51, effectively targeting RAD51 onto ssDNA over dsDNA and stimulating RAD51-mediated strand exchange, whereas BRC5, 6, 7, and 8 bind to the RAD51-ssDNA filament at high affinity (Carreira and Kowalczykowski 2011). These results have led to a model whereby the first class of repeats facilitates nucleation of RAD51 onto ssDNA and the second class stabilizes the nascent RAD51 nucleoprotein filament (Carreira and Kowalczykowski 2011).

The carboxy-terminal RAD51-binding site of BRCA2 shares no homology with the BRC repeats (Mizuta et al. 1997; Sharan et al. 1997). RAD51 binding to this region is regulated: it is abrogated by CDK phosphorylation at $\mathrm{S} 3291$ at $\mathrm{G}_{2} / \mathrm{M}$, leading to the hypothesis that it coordinates BRCA2 activity with cell-cycle progression (Esashi et al. 2005). BRCA2 S3291 is a key site for RAD51 binding, as both phosphomimic (S3291E) and phosphodefective (S3291A) mutations block RAD51 interaction (Esashi et al. 2005). Unlike the BRC repeats, a BRCA2 carboxy-terminal peptide selectively binds RAD51 filaments at the interface region between two RAD51 protomers, such that carboxy-terminal-binding functions to stabilize RAD51-ssDNA filaments (Davies and Pellegrini 2007; Esashi et al. 2007). Surprisingly, however, S3291 mutation confers little or no DNA-dam- age sensitivity and does not compromise HR in the context of full-length protein ( $\mathrm{Hucl}$ et al. 2008; Ayoub et al. 2009; Schlacher et al. 2011), although the mutation does compromise HR in crippled BRCA2 peptides that have defects in other functional domains (Siaud et al. 2011), implying that carboxy-terminal RAD51 binding is not essential for HR but can promote HR under some circumstances. However, RAD51 binding by the BRCA2 carboxyl terminus has been implicated in the protection of nascent DNA strands at stalled replication forks (Schlacher et al. 2011).

DMC1, the meiosis-specific RAD51 homo$\log$, has been shown to have a distinct binding site on BRCA2 from the BRC repeats and carboxyl terminus (a PheProPro motif) (Thorslund et al. 2007). However, disrupting the motif in the mouse does not have a discernible effect on DMC1 function and meiosis (Biswas et al. 2012), suggesting that DMC1 binds elsewhere, perhaps at sites also bound by RAD51.

\section{DNA and DSS1 Binding}

That BRCA2 is a DNA-binding protein was revealed in structural studies (Yang et al. 2002). The DNA-binding domain (DBD) consists of five components: a helical domain, three oligonucleotide-binding (OB) folds that bind ssDNA, and a tower domain with a three-helix bundle (3HB) at its end (Fig. 3). The $3 \mathrm{HB}$ is similar to the DNA-binding domain of Hin recombinase, suggesting dsDNA-binding activity. The helical domain, OB1 and OB2, interacts with the small, highly conserved DSS1 protein (Marston et al. 1999; Yang et al. 2002), which has been shown to promote HR in human cells (Gudmundsdottir et al. 2004; Li et al. 2006; Kristensen et al. 2010).

BRCA2 peptide mutants abrogated for DSS1 binding have impaired HR (Siaud et al. 2011), indicating that at least part of the HR function of DSS1 is through interaction with BRCA2. Biochemical studies have shown that DSS1 promotes the RAD51-loading activity of BRCA2 (Liu et al. 2010). DSS1 also appears to maintain the stability of BRCA2 protein in cells (Li et al. 2006), although an effect is not always 
R. Prakash et al.

observed (Gudmundsdottir et al. 2004). In the fungus Ustilago maydis, the ortholog of DSS1 is also required for $\mathrm{HR}$ by regulating Brh2, the U. maydis ortholog of BRCA2 (Kojic et al. 2003, 2005). In budding yeast, which does not have a BRCA2 homolog, the DSS1 homolog localizes to DSB break sites and promotes HRand NHEJ-mediated DSB repair, suggesting a BRCA2-independent function of DSS1 in DSB repair (Krogan et al. 2004). DSS1 is also found to interact with the $19 \mathrm{~S}$ proteasome, the relevance of which to BRCA2 function remains to be clarified.

Patient missense mutations are found throughout BRCA2 DBD domain (Yang et al. 2002). Mutations predicted to compromise either the structural integrity of the DBD domain and/or DSS1/DNA-binding affect function (Kuznetsov et al. 2008; Biswas et al. 2011, 2012; Siaud et al.2011). Moreover, mutation of ssDNA contact residues or deletion of the $3 \mathrm{HB}$ has detrimental effects on HR in reporter-based assays measuring BRCA2 peptide activity (Siaud et al. 2011). Surprisingly, a BRCA2 peptide deleted for the entire DBD is still functional in HR (Siaud et al. 2011); in fact, deletion of the DBD is one type of reversion mutation identified for BRCA2 (Edwards et al. 2008). These findings emphasize the plasticity of BRCA2 function in $\mathrm{HR}$. An intact DBD is required if it is present, but loss of the entire DBD can be tolerated for substantial HR function, as long as PALB2 interaction is intact (Siaud et al. 2011).

\section{BRCA2 Function and HR}

The earliest clues about the importance of BRCA2 in maintaining genome integrity came from observations that Brca2 mutant mice show early embryonic lethality and DNA repair defects (Connor et al. 1997; Ludwig et al. 1997; Sharan et al. 1997; Suzuki et al. 1997) similar to Rad51 mutant mice (Lim and Hasty 1996; Tsuzuki et al. 1996). At the same time, BRCA2 interaction with RAD51 was uncovered (Sharan et al. 1997; Wong et al. 1997) and BRCA2 was found to colocalize with RAD51 in damageinduced nuclear foci (Chen et al. 1998a). The requirement of BRCA2 in HR was directly dem- onstrated using HR reporters (Fig. 2B) (Moynahan et al. 2001b).

BRCA2 clearly acts at a distinct step in HR from that of BRCA1 (Stark et al. 2004). Although BRCA1-BARD1 promotes repair by both HR and SSA, BRCA2 promotes HR while suppressing SSA (Fig. 4) (Tutt et al. 2001; Stark et al. 2004). End resection presumably initiates normally in BRCA2 mutant cells, but ssDNA overhangs cannot be channeled into HR; instead, where present, complementary ssDNA overhangs anneal to each other. RAD51 disruption results in the same phenotype as BRCA2 loss, indicating that genetically BRCA2 acts at the same step in HR as RAD51 (Stark et al. 2004). Not surprisingly then, loss of 53BP1 does not rescue the viability of BRCA2-deficient cells, as it does with BRCA1-deficient cells (Bouwman et al. 2010).

Genetic and biochemical studies have also pointed to a RAD51 mediator activity of BRCA2. Remarkably, HR activity and genomic integrity are restored to BRCA2-deficient hamster cells by fusing a single BRC motif to the ssDNA-binding protein RPA (Saeki et al. 2006), suggesting that the main role of BRCA2 is to load RAD51 onto ssDNA. Purified Brh2 protein, the BRCA2 ortholog in the fungus $U$. maydis, stimulates Rad51-mediated strand exchange at an ssDNA-dsDNA junction by loading Rad51 onto DNA and displacing RPA (Yang et al. 2005). Recently, this RAD51-mediator function was further confirmed with purified human BRCA2, which specifically promotes RAD51 filament assembly on ssDNA over dsDNA ( Jensen et al. 2010; Liu et al. 2010; Thorslund et al.2010), leading to displacement of RPA to stimulate strand exchange (Jensen et al. 2010; Liu et al. 2010). Stabilization of RAD51-ssDNA complexes by BRCA2 occurs by inhibition of the DNA-dependent ATPase activity of RAD51. Although challenges exist studying this very large protein involved in multiple protein interactions, these studies are promising for understanding the biochemistry of BRCA2.

Consistent with its major role in $\mathrm{HR}$, BRCA2-deficient cells are sensitive to DNAdamaging agents that lead to lesions normally repaired by $\mathrm{HR}$, including cross-linking agents 
(Kraakman-van der Zwet et al. 2002) and to PARP inhibitors (Bryant et al. 2005; Farmer et al. 2005). BRCA2 has also been implicated in processes other than HR repair per se. Earlier studies suggested that stalled replication forks are stabilized by BRCA2 (Lomonosov et al. 2003). Recent work has provided evidence that this function is achieved through a RAD51-dependent, but HR-repair-independent mechanism, such that BRCA2 protects nascent DNA strand from degradation by stabilizing the RAD51 filament to maintain genomic integrity under replication stress (Schlacher et al. 2011). Roles for BRCA1 and canonical Fanconi anemia proteins have also been shown in nascent strand protection (Schlacher et al. 2012). The link between BRCA1, BRCA2, and Fanconi anemia proteins in replication fork protection is notable because loss of canonical Fanconi anemia proteins results in only mild HR defects in mammalian cells (Nakanishi et al. 2005), except for HR repair of cross links coupled to replication (Nakanishi et al. 2011).

\section{PALB2}

\section{PALB2 Mutations in Patients}

As with BRCA2, monoallelic PALB2 mutations are associated with breast cancer susceptibility (Erkko et al. 2007; Rahman et al. 2007; Tischkowitz et al. 2007). The breast cancer risk associated with PALB2 mutation has recently been estimated to overlap with that of BRCA2 mutation (Antoniou et al. 2014). Although mutations are generally infrequent compared with $B R C A 1$ and BRCA2, in the Finnish population $\sim 1 \%$ of unselected breast cancers are associated with a founder PALB2 mutation (Erkko et al. 2007). The clinical phenotype of breast cancers with PALB2 mutation is more similar to that of $B R C A 2$ in that a more substantial fraction is estrogen receptor positive rather than triple negative (Antoniou et al. 2014). Monoallelic PALB2 mutations have also been associated with pancreatic and ovarian cancer susceptibility (Jones et al. 2009; Walsh et al. 2011).

Biallelic PALB2 mutation leads to a Fanconi anemia subtype (FA-N), which shares a similar tumor spectrum with the FA-D1 subtype arising from $B R C A 2$ mutation. Patients are predisposed to developing early childhood cancers, such as Wilms' tumor and medulloblastoma (Reid et al. 2007; Xia et al. 2007). Further, homozygous germline deletion of Palb2 in mice leads to early embryonic lethality (Bouwman et al. 2011; Bowman-Colin et al. 2013), whereas conditional deletion of Palb2 causes mammary tumors with long latency accelerated by $\mathrm{p} 53$ loss (Bowman-Colin et al. 2013; Huo et al. 2013). As with BRCA2 but unlike BRCA1, 53BP1 loss fails to rescue genome instability caused by PALB2 deficiency (Bowman-Colin et al. 2013). These phenotypes are consistent with the notion that PALB2 and BRCA2 function in the same step of the HR pathway to maintain genome integrity and suppress tumor development.

\section{PALB2 Domains and Interactions}

PALB2 is an 1186 amino acid protein with a coiled-coil domain at its amino terminus, which interacts with BRCA1, and a WD40 $\beta$ propeller domain at its carboxyl terminus, which interacts with BRCA2 (Fig. 3) (Xia et al. 2006; Oliver et al. 2009; Sy et al. 2009; Zhang et al. 2009a,b). Emphasizing the importance of the PALB2 interaction for BRCA2 function, disruption of this interaction results in severe HR defects (Xia et al. 2006; Siaud et al. 2011). Furthermore, human BRCA2 mutations that abrogate PALB2 interaction fail to support viability of Brca2-null mouse embryonic stem cells (Biswas et al. 2012), although paradoxically Palb2null embryonic stem cells have been reported to be viable (Bowman-Colin et al. 2013).

\section{PALB2 and HR}

Biochemical studies have shown that purified PALB2 binds DNA and RAD51, and is able to stimulate RAD51-dependent strand invasion, including synergistically with a BRCA2 peptide (Buisson et al. 2010; Dray et al. 2010). A recent report also links both BRCA2 and PALB2 to a downstream step in HR, DNA synthesis, by stimulating polymerase $\eta$ activity on strand invasion intermediates (Buisson et al. 2014). 
R. Prakash et al.

\section{RAD51 PARALOGS}

\section{RAD51 Paralog Mutations in Patients}

RAD51 has five paralogs ( $R A D 51 B, R A D 51 C$, $R A D 51 D, X R C C 2$, and XRCC3) that were discovered both as RAD51-related genes and through their complementation of radiationsensitive Chinese hamster cell mutants (Tebbs et al. 1995; Albala et al. 1997; Cartwright et al. 1998; Dosanjh et al. 1998; Pittman et al. 1998). Thus far, the strongest evidence that RAD51 paralogs are tumor suppressors comes from studies of RAD51C and RAD51D. Monoallelic, germline mutations in these genes predispose to ovarian cancer (Meindl et al. 2010; Loveday et al. 2011, 2012), although the predisposition to breast cancer is less clear. However, in both cases, mutations have been observed in $\sim 1 \%$ of families with BRCA1/2-negative breast and ovarian cancer. Truncating mutations have been reported for both $R A D 51 C$ and $R A D 51 D$ and, in addition, missense mutations that impair the ATP-binding site have been reported for RAD51C (Meindl et al. 2010; Loveday et al. 2011, 2012; Somyajit et al. 2012).

RAD51B, XRCC2, and XRCC3 monoallelic mutations have also been observed in breast cancer families, although the significance is not certain (Hilbers et al. 2012; Park et al. 2012; Golmard et al. 2013). One unusual finding is the presence of chromosomal translocations involving $R A D 51 B$ in some benign tumors (Ingraham et al. 1999; Schoenmakers et al. 1999), including a germline translocation in a family with multiple cases of thymoma (Nicodeme et al. 2005). As reduced gene dosage of $R A D 51 B$ has been reported to have phenotypic consequences (Date et al. 2006), translocations involving one allele may reduce repair activity.

Biallelic missense mutations of RAD51C $(\mathrm{R} 258 \mathrm{H})$ were identified in one consanguineous family with three children with severe congenital abnormalities whose cells were sensitive to crosslinking agents (Vaz et al. 2010). Thus, biallelic $R A D 51 C$ mutation is now considered to confer a Fanconi anemia-like disorder, subtype FA-O. Two of the children with RAD51C mutation died as infants from the congenital defects; the surviving child was reported at 10 years of age to be cancer free. Some of the congenital abnormalities are similar to those described in FA-D1 and FA-N children with biallelic BRCA2 and PALB2 mutation, respectively; however, the absence of a malignancy in the older child is distinct (Moldovan and D'Andrea 2009). RAD51C R258 is close to the ATP-binding site and is highly conserved; the mutation has been shown to reduce but not abolish HR function (Somyajit et al. 2012). $X R C C 2$ is the only other RAD51 paralog besides $R A D 51 C$ for which a Fanconi anemia-like phenotype has been described to date. A child from a consanguineous family with an XRCC2 truncating mutation has been reported with developmental issues and cellular sensitivity to cross-linking agents (Shamseldin et al. 2012).

\section{RAD51 Paralog Complexes}

RAD51 paralogs show 20\%-30\% amino acid sequence similarity to RAD51 and with each other, and this sequence conservation is predominantly found at a globular domain with Walker A and B motifs, which are critical for the ATP-binding/hydrolysis activity. Protein homology modeling studies have predicted that the RAD51 paralogs, with the exception XRCC2, have an amino-terminal domain containing a four-helix bundle linked to the carboxy-terminal globular domain (Miller et al. 2004), similar to RAD51 (Shin et al. 2003). Yeast two-/ three-hybrid, coimmunoprecipitation studies, and biochemical studies have shown that RAD51 paralogs exist in two major complexes, RAD51B-RAD51C-RAD51D-XRCC2 (BCDX2) and RAD51C-XRCC3 (CX3) (Fig. 3), although subcomplexes have also been identified (BC, CD, DX2, BCD, and CDX2) (Braybrooke et al. 2000; Schild et al. 2000; Masson et al. 2001; Sigurdsson et al. 2001; Liu et al. 2002; Wiese et al. 2002). The amino-terminal domain of one paralog apparently makes contact with the carboxy-terminal domain of another, providing specificity to the interactions (e.g., RAD51BN-ter with RAD51C-C-ter, RAD51C-N-ter with RAD51D-C-ter, RAD51D-N-ter with XRCC2-C-ter) (Kurumizaka et al. 2003; Miller et al. 2004). Furthermore, RAD51 interactions with the BCDX2 and CX3 complexes and indi- 
vidual paralogs have also been reported (Dosanjh et al. 1998; Schild et al. 2000; Masson et al. 2001; Liu et al. 2002).

Biochemical activities of these various complexes and subcomplexes have been described, although their integration into HR pathways involving BRCA2 and other factors is not well understood. The RAD51 paralogs bind a variety of DNA structures, including ssDNA and branched structures like Holliday junctions (Braybrooke et al. 2000; Kurumizaka et al. 2001; Masson et al. 2001; Sigurdsson et al. 2001; Yokoyama et al. 2003, 2004; Liu et al. 2004). As expected, the RAD51 paralogs have been shown to hydrolyze ATP (Braybrooke et al. 2000; Sigurdsson et al. 2001; Lio et al. 2003; Yokoyama et al. 2003; Shim et al. 2004); an intact ATP hydrolysis domain is required for the function of several paralogs (French et al. 2003; Yamada et al. 2004; Gruver et al. 2005; Wiese et al. 2006), although not for XRCC2 (O'Regan et al. 2001). The BC subcomplex has been reported to stimulate RAD51 strand-exchange activity in the presence of RPA (Sigurdsson et al. 2001), apparently by stabilizing the RAD51 nucleoprotein filament rather than facilitating RAD51 nucleation (Amunugama et al. 2013).

\section{RAD51 Paralog Cellular Phenotypes}

A key role for the RAD51 paralogs in HR was initially shown for XRCC2 and XRCC3 in Chinese hamster cell mutants (Johnson et al. 1999; Pierce et al. 1999) and later for each of the paralogs in chicken B lymphocytes (Takata et al. 2001). As with biochemical studies in human cells, two distinct paralog complexes are predicted in chicken cells, given that mutations in two paralogs in the same complex are epistatic (Rad51B and Rad51D), whereas mutations in paralogs in two different complexes are not (Xrcc3 and Rad51D) (Yonetani et al. 2005). Overexpression of RAD51 in each of the chicken cell mutants partially suppresses DNA-damage sensitivity, indicating a role for each of the paralogs in RAD51 loading or filament stabilization (Takata et al. 2001). Overall, mammalian RAD51 paralog mutants display reduced DNAdamage-induced RAD51 focus formation and have increased spontaneous chromosomal abnormalities and are sensitive to DNA-damaging agents, such as cross-linking agents like cisplatin, and to PARP inhibitors (Bishop et al. 1998; Liu et al. 1998; Cui et al. 1999; Takata et al. 2001; French et al. 2002; Yoshihara et al. 2004; Smiraldo et al. 2005; Loveday et al. 2011; Urbin et al. 2012; Min et al. 2013).

An early role for RAD51 paralogs in HR pathways is supported by the rapid recruitment of XRCC3 to DSBs, which is independent of RAD51 (Forget et al. 2004). A later role in HR for RAD51 paralogs has also been investigated. RAD51C accumulates in nuclear foci in response to ionizing radiation where it colocalizes with RAD51; however, RAD51C foci persist for longer than RAD51 foci, suggesting that RAD51C, a component of both main complexes (BCDX2 and CX3), has a role in both early and late stages of HR (Badie et al. 2009). Like hamster and chicken cells, XRCC3 knockout HCT116 human cells were initially reported to have impaired RAD51 focus formation (Yoshihara et al. 2004); however, a recent study in these cells and in XRCC3 siRNA knockdown MCF7 cells reported no RAD51 focus formation defect, leading investigators to conclude that BCDX2 acts to load RAD51 onto DNA ends while CX3 acts after RAD51 loading (Chun et al. 2013). Consistent with a distinct role for XRCC3 among the paralogs, XRCC3 knockdown in HeLa cells results in a persistent spindle assembly checkpoint, whereas RAD51B or RAD51C knockdown induces a $\mathrm{G}_{2} / \mathrm{M}$ cell-cycle arrest (Rodrigue et al. 2013). Overall, these studies point to the need for a coherent mammalian model to dissect the roles of the individual paralogs in HR.

\section{RAD51 Paralog Mouse Knockout Models}

Mouse knockouts of four RAD51 paralogs (Rad51b, Rad51c, Rad51d, and Xrcc2) have been reported and each is embryonic lethal, implying a critical function at developmental stages when cells are rapidly dividing (Shu et al. 1999; Deans et al. 2000; Pittman and Schimenti 2000; Kuznetsov et al. 2009; Smeenk et al. 2010). No mouse model for Xrcc3 is currently 
available. The reported developmental stage of death is not equivalent in the various knockouts, suggesting possible distinct functions of the paralogs, although differences in genetic background of the various mutants may account for some of the phenotypic differences. Embryonic lethality does not appear to be defined by a specific developmental defect but, rather, the embryos show growth delays over the course of a few days, consistent with what might be expected from stochastic DNA damage that is not repaired.

Supporting repair defects leading to apoptosis as a cause of lethality, death is delayed a few days by Trp53 mutation, although postnatal viability is not restored (Shu et al. 1999; Smiraldo et al. 2005; Adam et al. 2007; Kuznetsov et al. 2009). The partial rescue by Trp53 mutation is similar to that observed with Rad51, Brca1, and Brca2 mutants (Moynahan 2002) but is unlike NHEJ mutants, in which the late embryonic lethality is rescued to give rise to viable (although feeble) mice (Frank et al. 2000; Gao et al. 2000). The one exception is $X r c c 2$, in which the viability of one of the two reported knockouts is rescued by Trp53 mutation (see below) (Orii et al. 2006).

A summary of the RAD51 paralog knockouts is as follows in order of embryonic death (Rad51b, Rad51c, Rad51d, Xrcc2):

Rad51b mutants have severe growth retardation by embryonic day E5.5 and by E8.5 are completely resorbed (Shu et al. 1999). Embryonic stem cell lines could not be derived, suggesting that loss of RAD51B is cell lethal, similar to RAD51, BRCA1, or BRCA2 (Moynahan 2002).

Rad51c mutants show abnormalities by E5.5, are severely retarded by E8.5, and are resorbed shortly thereafter (Kuznetsov et al. 2009). Rad51c and Trp53 are on the same chromosome, and adult mice that are heterozygous for both genes in cis develop a tumor spectrum (including mammary and preputial gland tumors) that differs from mice either with both mutations in trans or with Trp53 mutation alone. The difference in the cis and trans mice is because $\mathrm{LOH}$ allows tu- mors to develop, which are null for both Rad51c and Trp53. A hypomorphic Rad51c mutant has also been described in which RAD51C levels are reduced significantly $(\leq 30 \%)$ (Kuznetsov et al. 2007). This level of expression is sufficient to give rise to viable mice; however, a significant fraction is infertile owing to meiotic defects, including reduced RAD51 foci and the presence of unrepaired DSBs in spermatocytes.

Rad51d embryos display a range of abnormalities between E7.5 and 10.5, and none are viable by E11.5 (Pittman and Schimenti 2000). Trp53 mutation leads to a significant rescue, such that embryos are detected as late as E16.5, although they are growth retarded (Smiraldo et al. 2005). Rad51d is located between Rad51c and Trp53; mice with Rad51d and Trp53 heterozygous mutations in cis are not tumor prone up to 12 months of age.

Xrcc2 mutants develop normally to E8.5; thereafter, they display developmental delay/defects and are found at sub-Mendelian ratios (Deans et al. 2000). The few mice that are born succumb soon after birth. However, when $X r c c 2$ mice are backcrossed onto a C57BL/6 genetic background, embryos do not reach late embryogenesis, although combined Trp53 mutation allows some embryos to survive until just before birth (Adam et al. 2007). In another knockout model, presumably on a mixed genetic background, Trp53 mutation actually rescues the viability of Xrcc2 mice (Orii et al. 2006).

Apoptosis is elevated throughout $X r c c 2$ mutant embryos (Deans et al. 2000), especially in the brain in proliferating cells, which is distinct from Lig4 mutant embryos where it predominates in postmitotic cells (Fig. 2C) (Orii et al. 2006). Trp53 mutation suppresses apoptosis in the developing brain and rescues the viability of Xrcc2 mutant mice in this model, as it does to Lig4 mutant mice (Frank et al. 2000; Orii et al. 2006), permitting a comparison of postnatal phenotypes, such as tumorigenesis. Although Lig4/Trp53 null mice succumb to $M y c$-amplified B cell lymphoma and medulloblastoma by 
3 months of age (Frank et al. 2000; Lee and McKinnon 2002), Xrcc2/Trp53 null mice have a broad tumor spectrum with an earlier onset without obvious $M y c$ amplification (Orii et al. 2006). Thus, both HR and NHEJ are important for the viability of mice and tumor suppression, although their roles differ.

Rad51c/Trp53, Rad51d/Trp53, and Xrcc2/ Trp53 mouse embryonic fibroblasts have been established (Smiraldo et al. 2005; Adam et al. 2007; Kuznetsov et al. 2009), as have Xrcc2 embryonic stem cell lines (Deans et al. 2003). These RAD51 paralog mutant cells are sensitive to DNA-damaging agents, such as ionizing radiation and interstrand cross-links, have defects in RAD51 foci formation, increased genomic instability, and, where checked, decreased HR in reporter assays. Rad51d/Trp53 fibroblasts have shortened telomeres, suggesting that RAD51D plays a role in telomere maintenance (Tarsounas et al. 2004).

\section{SUMMARY AND FUTURE DIRECTIONS}

Genetic studies have revealed a link between germline mutations in several HR genes and predisposition to breast/ovarian and other tumors. Somatic mutations in HR genes have also been uncovered (Cancer Genome Atlas Research Network 2011; Pennington et al. 2014). Insight into the molecular functions of the various HR proteins has been forthcoming. A role for BRCA1 in the end resection step of HR is well supported. At least three mechanisms are implicated: antagonizing the resection inhibitor 53BP1, promoting resection in the BRCA1-C complex with CtIP, and inhibiting resection in the BRCA1-A complex through AbraxasRAP80. The BRCA1-PALB2-BRCA2 complex and RAD51 paralogs cooperate to load RAD51 onto ssDNA coated with RPA to form the essential recombination intermediate, the RAD51ssDNA filament. The crucial role of these genes in key steps of HR provides important clues for understanding the cause of cancer in patients with mutations in these genes and for investigating more effective cancer treatments.

However, many key questions remain to be addressed. For instance, how are the various roles of BRCA1 orchestrated? How do so many players, including the BRCA1-PALB2-BRCA2 complex and RAD51 paralog complexes, collaborate to load and stabilize RAD51 onto ssDNA? Importantly, how exactly does HR deficiency specifically contribute to ovarian/breast carcinogenesis and other cancer-prone diseases, such as Fanconi anemia? And how are other potential functions of HR proteins integrated into their tumor suppressor roles? A comprehensive understanding of disease-linked components and mechanisms of HR in mammalian system will be vital, including for therapeutic approaches that target the HR pathway.

\section{ACKNOWLEDGMENTS}

We thank previous members of the Jasin Laboratory whose work is referenced in this review. This work is supported by National Institutes of Health GM110978 (to R.P.) and CA185660 and GM054668 (to M.J.).

\section{REFERENCES}

\section{* Reference is also in this collection.}

Adam J, Deans B, Thacker J. 2007. A role for Xrcc2 in the early stages of mouse development. DNA Repair (Amst) 6: $224-234$.

Albala JS, Thelen MP, Prange C, Fan W, Christensen M, Thompson LH, Lennon GG. 1997. Identification of a novel human RAD51 homolog, RAD51B. Genomics 46: 476-479.

Amunugama R, Groden J, Fishel R. 2013. The HsRAD51BHsRAD51C stabilizes the HsRAD51 nucleoprotein filament. DNA Repair (Amst) 12: 723-732.

Antoniou A, Pharoah PD, Narod S, Risch HA, Eyfjord JE, Hopper JL, Loman N, Olsson H, Johannsson O, Borg A, et al. 2003. Average risks of breast and ovarian cancer associated with BRCA1 or BRCA2 mutations detected in case series unselected for family history: A combined analysis of 22 studies. Am J Hum Genet 72: 1117-1130.

Antoniou AC, Casadei S, Heikkinen T, Barrowdale D, Pylkas K, Roberts J, Lee A, Subramanian D, De Leeneer K, Fostira F, et al. 2014. Breast-cancer risk in families with mutations in PALB2. N Engl J Med 371: 497-506.

Ayoub N, Rajendra E, Su X, Jeyasekharan AD, Mahen R, Venkitaraman AR. 2009. The carboxyl terminus of Brca2 links the disassembly of Rad51 complexes to mitotic entry. Curr Biol 19: 1075-1085.

Badie S, Liao C, Thanasoula M, Barber P, Hill MA, Tarsounas M. 2009. RAD51C facilitates checkpoint signaling by promoting CHK2 phosphorylation. J Cell Biol 185: 587600 . 
R. Prakash et al.

Bignell G, Micklem G, Stratton MR, Ashworth A, Wooster R. 1997. The BRC repeats are conserved in mammalian BRCA2 proteins. Hum Mol Genet 6: 53-58.

Bishop DK, Ear U, Bhattacharyya A, Calderone C, Beckett M, Weichselbaum RR, Shinohara A. 1998. Xrcc3 is required for assembly of Rad51 complexes in vivo. J Biol Chem 273: 21482-21488.

Biswas K, Das R, Alter BP, Kuznetsov SG, Stauffer S, North SL, Burkett S, Brody LC, Meyer S, Byrd RA, et al. 2011. A comprehensive functional characterization of BRCA2 variants associated with Fanconi anemia using mouse ES cell-based assay. Blood 118: 2430-2442.

Biswas K, Das R, Eggington JM, Qiao H, North SL, Stauffer S, Burkett SS, Martin BK, Southon E, Sizemore SC, et al. 2012. Functional evaluation of BRCA2 variants mapping to the PALB2-binding and C-terminal DNA-binding domains using a mouse ES cell-based assay. Hum Mol Genet 21: 3993-4006.

* Bizard AH, Hickson ID. 2014. The dissolution of double Holliday junctions. Cold Spring Harb Perspect Biol 6: a016477.

Bouwman P, Aly A, Escandell JM, Pieterse M, Bartkova J, van der Gulden H, Hiddingh S, Thanasoula M, Kulkarni A, Yang Q, et al. 2010. 53BP1 loss rescues BRCA1 deficiency and is associated with triple-negative and BRCAmutated breast cancers. Nat Struct Mol Biol 17: 688-695.

Bouwman P, Drost R, Klijn C, Pieterse M, van der Gulden H, Song JY, Szuhai K, Jonkers J. 2011. Loss of p53 partially rescues embryonic development of Palb2 knockout mice but does not foster haploinsufficiency of Palb2 in tumour suppression. J Pathol 224: 10-21.

Bouwman P, van der Gulden H, van der Heijden I, Drost R, Klijn CN, Prasetyanti P, Pieterse M, Wientjens E, Seibler J, Hogervorst FB, et al. 2013. A high-throughput functional complementation assay for classification of BRCA1 missense variants. Cancer Discov 3: 1142-1155.

Bowman-Colin C, Xia B, Bunting S, Klijn C, Drost R, Bouwman P, Fineman L, Chen X, Culhane AC, Cai H, et al. 2013. Palb2 synergizes with Trp53 to suppress mammary tumor formation in a model of inherited breast cancer. Proc Natl Acad Sci 110: 8632-8637.

Braybrooke JP, Spink KG, Thacker J, Hickson ID. 2000. The RAD51 family member, RAD51L3, is a DNA-stimulated ATPase that forms a complex with XRCC2. J Biol Chem 275: $29100-29106$.

Bryant HE, Schultz N, Thomas HD, Parker KM, Flower D, Lopez E, Kyle S, Meuth M, Curtin NJ, Helleday T. 2005. Specific killing of BRCA2-deficient tumours with inhibitors of poly(ADP-ribose) polymerase. Nature 434: 913 917.

Brzovic PS, Rajagopal P, Hoyt DW, King MC, Klevit RE. 2001. Structure of a BRCA1-BARD1 heterodimeric RING-RING complex. Nat Struct Biol 8: 833-837.

Buis J, Stoneham T, Spehalski E, Ferguson DO. 2012. Mre11 regulates CtIP-dependent double-strand break repair by interaction with CDK2. Nat Struct Mol Biol 19: 246-252.

Buisson R, Dion-Cote AM, Coulombe Y, Launay H, Cai H, Stasiak AZ, Stasiak A, Xia B, Masson JY. 2010. Cooperation of breast cancer proteins PALB2 and piccolo BRCA2 in stimulating homologous recombination. Nat Struct Mol Biol 17: 1247-1254.
Buisson R, Niraj J, Pauty J, Maity R, Zhao W, Coulombe Y, Sung P, Masson JY. 2014. Breast cancer proteins PALB2 and BRCA2 stimulate polymerase $\eta$ in recombinationassociated DNA synthesis at blocked replication forks. Cell Rep 6: 553-564.

Bunting SF, Callen E, Wong N, Chen HT, Polato F, Gunn A, Bothmer A, Feldhahn N, Fernandez-Capetillo O, Cao L, et al. 2010. 53BP1 inhibits homologous recombination in Brcal-deficient cells by blocking resection of DNA breaks. Cell 141: 243-254.

Bunting SF, Callen E, Kozak ML, Kim JM, Wong N, LopezContreras AJ, Ludwig T, Baer R, Faryabi RB, Malhowski A, et al. 2012. BRCA1 functions independently of homologous recombination in DNA interstrand crosslink repair. Mol Cell 46: 125-135.

Caleca L, Putignano AL, Colombo M, Congregati C, Sarkar M, Magliery TJ, Ripamonti CB, Foglia C, Peissel B, Zaffaroni D, et al. 2014. Characterization of an Italian founder mutation in the RING-finger domain of BRCA1. PLoS ONE 9: e86924.

Cancer Genome Atlas Research Network. 2011. Integrated genomic analyses of ovarian carcinoma. Nature 474: 609-615.

Cantor SB, Bell DW, Ganesan S, Kass EM, Drapkin R, Grossman S, Wahrer DC, Sgroi DC, Lane WS, Haber DA, et al. 2001. BACH1, a novel helicase-like protein, interacts directly with BRCA1 and contributes to its DNA repair function. Cell 105: 149-160.

Cantor S, Drapkin R, Zhang F, Lin Y, Han J, Pamidi S, Livingston DM. 2004. The BRCA1-associated protein BACH1 is a DNA helicase targeted by clinically relevant inactivating mutations. Proc Natl Acad Sci 101: 23572362.

Carreira A, Kowalczykowski SC. 2011. Two classes of BRC repeats in BRCA2 promote RAD51 nucleoprotein filament function by distinct mechanisms. Proc Natl Acad Sci 108: $10448-10453$.

Carreira A, Hilario J, Amitani I, Baskin RJ, Shivji MK, Venkitaraman AR, Kowalczykowski SC. 2009. The BRC repeats of BRCA2 modulate the DNA-binding selectivity of RAD51. Cell 136: 1032-1043.

Cartwright R, Tambini CE, Simpson PJ, Thacker J. 1998. The XRCC2 DNA repair gene from human and mouse encodes a novel member of the recA/RAD51 family. $\mathrm{Nu}$ cleic Acids Res 26: 3084-3089.

Chang S, Biswas K, Martin BK, Stauffer S, Sharan SK. 2009. Expression of human BRCA1 variants in mouse ES cells allows functional analysis of BRCA1 mutations. J Clin Invest 119: $3160-3171$.

Chapman JR, Sossick AJ, Boulton SJ, Jackson SP. 2012a. BRCA1-associated exclusion of 53BP1 from DNA damage sites underlies temporal control of DNA repair. J Cell Sci 125: 3529-3534.

Chapman JR, Taylor MR, Boulton SJ. 2012b. Playing the end game: DNA double-strand break repair pathway choice. Mol Cell 47: 497-510.

Chapman JR, Barral P, Vannier JB, Borel V, Steger M, TomasLoba A, Sartori AA, Adams IR, Batista FD, Boulton SJ. 2013. RIF1 is essential for 53BP1-dependent nonhomologous end joining and suppression of DNA doublestrand break resection. Mol Cell 49: 858-871. 
Chen J, Silver DP, Walpita D, Cantor SB, Gazdar AF, Tomlinson G, Couch FJ, Weber BL, Ashley T, Livingston DM, et al. 1998a. Stable interaction between the products of the BRCA1 and BRCA2 tumor suppressor genes in $\mathrm{mi}-$ totic and meiotic cells. Mol Cell 2: 317-328.

Chen PL, Chen CF, Chen Y, Xiao J, Sharp ZD, Lee WH. 1998b. The BRC repeats in BRCA2 are critical for RAD51 binding and resistance to methyl methanesulfonate treatment. Proc Natl Acad Sci 95: 5287-5292.

Chen CF, Chen PL, Zhong Q, Sharp ZD, Lee WH. 1999. Expression of BRC repeats in breast cancer cells disrupts the BRCA2-Rad51 complex and leads to radiation hypersensitivity and loss of $\mathrm{G}_{2} / \mathrm{M}$ checkpoint control. J Biol Chem 274: 32931-32935.

Chen L, Nievera CJ, Lee AY, Wu X. 2008. Cell cycle-dependent complex formation of BRCA1.CtIP.MRN is important for DNA double-strand break repair. J Biol Chem 283: $7713-7720$

Choi E, Park PG, Lee HO, Lee YK, Kang GH, Lee JW, Han W, Lee HC, Noh DY, Lekomtsev S, et al. 2012. BRCA2 finetunes the spindle assembly checkpoint through reinforcement of BubR1 acetylation. Dev Cell 22: 295-308.

Christensen DE, Brzovic PS, Klevit RE. 2007. E2-BRCA1 RING interactions dictate synthesis of mono- or specific polyubiquitin chain linkages. Nat Struct Mol Biol 14: 941-948.

Chun J, Buechelmaier ES, Powell SN. 2013. Rad51 paralog complexes BCDX2 and CX3 act at different stages in the BRCA1-BRCA2-dependent homologous recombination pathway. Mol Cell Biol 33: 387-395.

Coleman KA, Greenberg RA. 2011. The BRCA1-RAP80 complex regulates DNA repair mechanism utilization by restricting end resection. J Biol Chem 286: 1366913680.

Collins N, McManus R, Wooster R, Mangion J, Seal S, Lakhani SR, Ormiston W, Daly PA, Ford D, Easton DF et al. 1995. Consistent loss of the wild type allele in breast cancers from a family linked to the BRCA2 gene on chromosome 13q12-13. Oncogene 10: 1673-1675.

Cong L, Ran FA, Cox D, Lin S, Barretto R, Habib N, Hsu PD, Wu X, Jiang W, Marraffini LA, et al. 2013. Multiplex genome engineering using CRISPR/Cas systems. Science 339: 819-823.

Connor F, Bertwistle D, Mee PJ, Ross GM, Swift S, Grigorieva E, Tybulewicz VL, Ashworth A. 1997. Tumorigenesis and a DNA repair defect in mice with a truncating Brca2 mutation. Nat Genet 17: 423-430.

Consortium BCL. 1999. Cancer risks in BRCA2 mutation carriers. J Natl Cancer Inst 91: 1310-1316.

Couedel C, Mills KD, Barchi M, Shen L, Olshen A, Johnson RD, Nussenzweig A, Essers J, Kanaar R, Li GC, et al. 2004 Collaboration of homologous recombination and nonhomologous end-joining factors for the survival and integrity of mice and cells. Genes Dev 18: 1293-1304.

Cox MM, Goodman MF, Kreuzer KN, Sherratt DJ, Sandler SJ, Marians KJ. 2000. The importance of repairing stalled replication forks. Nature 404: 37-41.

Cui X, Brenneman M, Meyne J, Oshimura M, Goodwin EH, Chen DJ. 1999. The XRCC2 and XRCC3 repair genes are required for chromosome stability in mammalian cells. Mutat Res 434: 75-88.
* Daley JM, Gaines WA, Kwon YH, Sung P. 2014. Regulation of DNA pairing in homologous recombination. Cold Spring Harb Perspect Biol 6: a017954.

D'Andrea AD. 2013. BRCA1: A missing link in the Fanconi anemia/BRCA pathway. Cancer Discov 3: 376-378.

Daniels MJ, Wang Y, Lee M, Venkitaraman AR. 2004. Abnormal cytokinesis in cells deficient in the breast cancer susceptibility protein BRCA2. Science 306: 876-879.

Date O, Katsura M, Ishida M, Yoshihara T, Kinomura A, Sueda T, Miyagawa K. 2006. Haploinsufficiency of RAD51B causes centrosome fragmentation and aneuploidy in human cells. Cancer Res 66: 6018-6024.

Daugaard M, Baude A, Fugger K, Povlsen LK, Beck H, Sorensen CS, Petersen NH, Sorensen PH, Lukas C, Bartek J, et al. 2012. LEDGF ( $\mathrm{p} 75$ ) promotes DNA-end resection and homologous recombination. Nat Struct Mol Biol 19: 803-810.

Davies OR, Pellegrini L. 2007. Interaction with the BRCA2 C terminus protects RAD51-DNA filaments from disassembly by BRC repeats. Nat Struct Mol Biol 14: 475-483.

Davies AA, Masson JY, McIlwraith MJ, Stasiak AZ, Stasiak A Venkitaraman AR, West SC. 2001. Role of BRCA2 in control of the RAD51 recombination and DNA repair protein. Mol Cell 7: 273-282.

Deans B, Griffin CS, Maconochie M, Thacker J. 2000. Xrcc2 is required for genetic stability, embryonic neurogenesis and viability in mice. $E M B O J$ 19: 6675-6685.

Deans B, Griffin CS, O’Regan P, Jasin M, Thacker J. 2003. Homologous recombination deficiency leads to profound genetic instability in cells derived from Xrcc2knockout mice. Cancer Res 63: 8181-8187.

De Brakeleer S, De Greve J, Loris R, Janin N, Lissens W, Sermijn E, Teugels E. 2010. Cancer predisposing missense and protein truncating $B A R D 1$ mutations in non-BRCA1 or BRCA2 breast cancer families. Hum Mutat 31: E1175E1185.

Dever SM, Golding SE, Rosenberg E, Adams BR, Idowu MO, Quillin JM, Valerie N, Xu B, Povirk LF, Valerie K. 2011. Mutations in the BRCT binding site of BRCA1 result in hyper-recombination. Aging (Albany NY) 3: 515-532.

Doil C, Mailand N, Bekker-Jensen S, Menard P, Larsen DH, Pepperkok R, Ellenberg J, Panier S, Durocher D, Bartek J, et al. 2009. RNF168 binds and amplifies ubiquitin conjugates on damaged chromosomes to allow accumulation of repair proteins. Cell 136: 435-446.

Domchek SM, Tang J, Stopfer J, Lilli DR, Hamel N, Tischkowitz M, Monteiro AN, Messick TE, Powers J, Yonker A, et al. 2013. Biallelic deleterious BRCA1 mutations in a woman with early-onset ovarian cancer. Cancer Discov 3: 399-405.

Dosanjh MK, Collins DW, Fan W, Lennon GG, Albala JS, Shen Z, Schild D. 1998. Isolation and characterization of $R A D 51 C$, a new human member of the RAD51 family of related genes. Nucleic Acids Res 26: 1179-1184.

Dray E, Etchin J, Wiese C, Saro D, Williams GJ, Hammel M, Yu X, Galkin VE, Liu D, Tsai MS, et al. 2010. Enhancement of RAD51 recombinase activity by the tumor suppressor PALB2. Nat Struct Mol Biol 17: 1255-1259.

Drost R, Bouwman P, Rottenberg S, Boon U, Schut E, Klarenbeek S, Klijn C, van der Heijden I, van der Gulden $\mathrm{H}$, Wientjens E, et al. 2011. BRCA1 RING function is essen- 
R. Prakash et al.

tial for tumor suppression but dispensable for therapy resistance. Cancer Cell 20: 797-809.

Edwards SM, Kote-Jarai Z, Meitz J, Hamoudi R, Hope Q Osin P, Jackson R, Southgate C, Singh R, Falconer A, et al. 2003. Two percent of men with early-onset prostate cancer harbor germline mutations in the BRCA2 gene. Am J Hum Genet 72: 1-12.

Edwards SL, Brough R, Lord CJ, Natrajan R, Vatcheva R, Levine DA, Boyd J, Reis-Filho JS, Ashworth A. 2008. Resistance to therapy caused by intragenic deletion in BRCA2. Nature 451: 1111-1115.

Erkko H, Xia B, Nikkila J, Schleutker J, Syrjakoski K, Mannermaa A, Kallioniemi A, Pylkas K, Karppinen SM, Rapakko K, et al. 2007. A recurrent mutation in PALB2 in Finnish cancer families. Nature 446: 316-319.

Esashi F, Christ N, Gannon J, Liu Y, Hunt T, Jasin M, West SC. 2005. CDK-dependent phosphorylation of BRCA2 as a regulatory mechanism for recombinational repair. $\mathrm{Na}$ ture 434: 598-604.

Esashi F, Galkin VE, Yu X, Egelman EH, West SC. 2007. Stabilization of RAD51 nucleoprotein filaments by the C-terminal region of BRCA2. Nat Struct Mol Biol 14: $468-474$.

Escribano-Diaz C, Orthwein A, Fradet-Turcotte A, Xing M, Young JT, Tkac J, Cook MA, Rosebrock AP, Munro M, Canny MD, et al. 2013. A cell cycle-dependent regulatory circuit composed of 53BP1-RIF1 and BRCA1-CtIP controls DNA repair pathway choice. Mol Cell 49: 872-883.

Essers J, Hendriks RW, Swagemakers SM, Troelstra C, de Wit J, Bootsma D, Hoeijmakers JH, Kanaar R. 1997. Disruption of mouse RAD54 reduces ionizing radiation resistance and homologous recombination. Cell 89: 195-204.

Farmer H, McCabe N, Lord CJ, Tutt AN, Johnson DA, Richardson TB, Santarosa M, Dillon KJ, Hickson I, Knights C, et al. 2005. Targeting the DNA repair defect in BRCA mutant cells as a therapeutic strategy. Nature 434: 917-921.

Feng L, Fong KW, Wang J, Wang W, Chen J. 2013. RIF1 counteracts BRCA1-mediated end resection during DNA repair. J Biol Chem 288: 11135-11143.

Forget AL, Bennett BT, Knight KL. 2004. Xrcc3 is recruited to DNA double strand breaks early and independent of Rad51. J Cell Biochem 93: 429-436.

Foulkes WD, Stefansson IM, Chappuis PO, Begin LR, Goffin JR, Wong N, Trudel M, Akslen LA. 2003. Germline BRCA1 mutations and a basal epithelial phenotype in breast cancer. J Natl Cancer Inst 95: 1482-1485.

Frank KM, Sharpless NE, Gao Y, Sekiguchi JM, Ferguson DO, Zhu C, Manis JP, Horner J, DePinho RA, Alt FW 2000. DNA ligase IV deficiency in mice leads to defective neurogenesis and embryonic lethality via the p53 pathway. Mol Cell 5: 993-1002.

French CA, Masson JY, Griffin CS, O'Regan P, West SC, Thacker J. 2002. Role of mammalian RAD51L2 (RAD51C) in recombination and genetic stability. J Biol Chem 277: 19322-19330.

French CA, Tambini CE, Thacker J. 2003. Identification of functional domains in the RAD51L2 (RAD51C) protein and its requirement for gene conversion. J Biol Chem 278: 45445-45450.
Friedman LS, Thistlethwaite FC, Patel KJ, Yu VP, Lee H, Venkitaraman AR, Abel KJ, Carlton MB, Hunter SM, Colledge WH, et al. 1998. Thymic lymphomas in mice with a truncating mutation in Brca2. Cancer Res 58: $1338-1343$.

Futreal PA, Liu Q, Shattuck-Eidens D, Cochran C, Harshman K, Tavtigian S, Bennett LM, Haugen-Strano A Swensen J, Miki Y, et al. 1994. BRCA1 mutations in primary breast and ovarian carcinomas. Science 266: 120 122.

Galkin VE, Esashi F, Yu X, Yang S, West SC, Egelman EH. 2005. BRCA2 BRC motifs bind RAD51-DNA filaments. Proc Natl Acad Sci 102: 8537-8542.

Gao Y, Ferguson DO, Xie W, Manis JP, Sekiguchi J, Frank KM, Chaudhuri J, Horner J, DePinho RA, Alt FW. 2000. Interplay of p53 and DNA-repair protein XRCC4 in tumorigenesis, genomic stability and development. Nature 404: 897-900.

Golmard L, Caux-Moncoutier V, Davy G, Al Ageeli E, Poirot B, Tirapo C, Michaux D, Barbaroux C, d'Enghien CD, Nicolas A, et al. 2013. Germline mutation in the RAD51B gene confers predisposition to breast cancer. BMC Cancer 13: 484 .

Greenberg RA, Sobhian B, Pathania S, Cantor SB, Nakatani Y, Livingston DM. 2006. Multifactorial contributions to an acute DNA damage response by BRCA1/BARD1-containing complexes. Genes Dev 20: 34-46.

Gruver AM, Miller KA, Rajesh C, Smiraldo PG, Kaliyaperumal S, Balder R, Stiles KM, Albala JS, Pittman DL. 2005 The ATPase motif in RAD51D is required for resistance to DNA interstrand crosslinking agents and interaction with RAD51C. Mutagenesis 20: 433-440.

Gudmundsdottir K, Lord CJ, Witt E, Tutt AN, Ashworth A. 2004. DSS1 is required for RAD51 focus formation and genomic stability in mammalian cells. EMBO Rep 5: 989-993.

Gudmundsson J, Johannesdottir G, Bergthorsson JT, Arason A, Ingvarsson S, Egilsson V, Barkardottir RB. 1995 Different tumor types from BRCA2 carriers show wildtype chromosome deletions on 13q12-q13. Cancer Res 55: $4830-4832$.

Hilbers FS, Wijnen JT, Hoogerbrugge N, Oosterwijk JC, Collee MJ, Peterlongo P, Radice P, Manoukian S, Feroce I, Capra F, et al. 2012. Rare variants in XRCC2 as breast cancer susceptibility alleles. J Med Genet 49: 618-620.

Howlett NG, Taniguchi T, Olson S, Cox B, Waisfisz Q, De Die-Smulders C, Persky N, Grompe M, Joenje H, Pals G, et al. 2002. Biallelic inactivation of BRCA2 in Fanconi anemia. Science 297: 606-609.

Hu Y, Scully R, Sobhian B, Xie A, Shestakova E, Livingston DM. 2011. RAP80-directed tuning of BRCA1 homologous recombination function at ionizing radiation-induced nuclear foci. Genes Dev 25: 685-700.

Hucl T, Rago C, Gallmeier E, Brody JR, Gorospe M, Kern SE. 2008. A syngeneic variance library for functional annotation of human variation: Application to BRCA2. Cancer Res 68: 5023-5030.

Huen MS, Grant R, Manke I, Minn K, Yu X, Yaffe MB, Chen J. 2007. RNF8 transduces the DNA-damage signal via histone ubiquitylation and checkpoint protein assembly. Cell 131: 901-914. 
Huen MS, Sy SM, Chen J. 2010. BRCA1 and its toolbox for the maintenance of genome integrity. Nat Rev Mol Cell Biol 11: 138-148.

Huo Y, Cai H, Teplova I, Bowman-Colin C, Chen G, Price S, Barnard N, Ganesan S, Karantza V, White E, et al. 2013. Autophagy opposes p53-mediated tumor barrier to facilitate tumorigenesis in a model of PALB2-associated hereditary breast cancer. Cancer Discov 3: 894-907.

Ingraham SE, Lynch RA, Kathiresan S, Buckler AJ, Menon AG. 1999. hREC2, a RAD51-like gene, is disrupted by $\mathrm{t}(12 ; 14)(\mathrm{q} 15 ; \mathrm{q} 24.1)$ in a uterine leiomyoma. Cancer $\mathrm{Ge}$ net Cytogenet 115: 56-61.

Jasin M, Rothstein R. 2013. Repair of strand breaks by homologous recombination. Cold Spring Harb Perspect Biol 5: a012740.

Jensen RB, Carreira A, Kowalczykowski SC. 2010. Purified human BRCA2 stimulates RAD51-mediated recombination. Nature 467: 678-683.

Johnson RD, Jasin M. 2000. Sister chromatid gene conversion is a prominent double-strand break repair pathway in mammalian cells. EMBO J 19: 3398-3407.

Johnson RD, Jasin M. 2001. Double-strand-break-induced homologous recombination in mammalian cells. Biochem Soc Trans 29: 196-201.

Johnson RD, Liu N, Jasin M. 1999. Mammalian XRCC2 promotes the repair of DNA double-strand breaks by homologous recombination. Nature 401: 397-399.

Johnson N, Johnson SF, Yao W, Li YC, Choi YE, Bernhardy AJ, Wang Y, Capelletti M, Sarosiek KA, Moreau LA, et al. 2013. Stabilization of mutant BRCA1 protein confers PARP inhibitor and platinum resistance. Proc Natl Acad Sci 110: 17041-17046.

Jones S, Hruban RH, Kamiyama M, Borges M, Zhang X, Parsons DW, Lin JC, Palmisano E, Brune K, Jaffee EM, et al. 2009. Exomic sequencing identifies PALB2 as a pancreatic cancer susceptibility gene. Science 324: 217.

Jonkers J, Meuwissen R, van der Gulden H, Peterse H, van der Valk M, Berns A. 2001. Synergistic tumor suppressor activity of BRCA2 and p53 in a conditional mouse model for breast cancer. Nat Genet 29: 418-425.

Jonsson G, Staaf J, Vallon-Christersson J, Ringner M, Holm K, Hegardt C, Gunnarsson H, Fagerholm R, Strand C, Agnarsson BA, et al. 2010. Genomic subtypes of breast cancer identified by array-comparative genomic hybridization display distinct molecular and clinical characteristics. Breast Cancer Res 12: R42.

Kakarougkas A, Ismail A, Katsuki Y, Freire R, Shibata A, Jeggo PA. 2013. Co-operation of BRCA1 and POH1 relieves the barriers posed by 53BP1 and RAP 80 to resection. Nucleic Acids Res 41: 10298-10311.

Kass EM, Jasin M. 2010. Collaboration and competition between DNA double-strand break repair pathways. FEBS Lett 584: 3703-3708.

Kim H, Chen J, Yu X. 2007. Ubiquitin-binding protein RAP80 mediates BRCA1-dependent DNA damage response. Science 316: 1202-1205.

King MC. 2014. "The race" to clone BRCA1. Science 343: $1462-1465$.

King MC, Marks JH, Mandell JB. 2003. Breast and ovarian cancer risks due to inherited mutations in BRCA1 and BRCA2. Science 302: 643-646.
King TA, Li W, Brogi E, Yee CJ, Gemignani ML, Olvera N, Levine DA, Norton L, Robson ME, Offit K, et al. 2007. Heterogenic loss of the wild-type BRCA allele in human breast tumorigenesis. Ann Surg Oncol 14: 2510-2518.

Kojic M, Yang H, Kostrub CF, Pavletich NP, Holloman WK. 2003. The BRCA2-interacting protein DSS1 is vital for DNA repair, recombination, and genome stability in Ustilago maydis. Mol Cell 12: 1043-1049.

Kojic M, Zhou Q, Lisby M, Holloman WK. 2005. Brh2-Dss1 interplay enables properly controlled recombination in Ustilago maydis. Mol Cell Biol 25: 2547-2557.

Kraakman-van der Zwet M, Overkamp WJ, van Lange RE, Essers J, van Duijn-Goedhart A, Wiggers I, Swaminathan S, van Buul PP, Errami A, Tan RT, et al. 2002. Brca2 (XRCC11) deficiency results in radioresistant DNA synthesis and a higher frequency of spontaneous deletions. Mol Cell Biol 22: 669-679.

Kristensen CN, Bystol KM, Li B, Serrano L, Brenneman MA. 2010. Depletion of DSS1 protein disables homologous recombinational repair in human cells. Mutation Res 694: 60-64.

Krogan NJ, Lam MH, Fillingham J, Keogh MC, Gebbia M, Li J, Datta N, Cagney G, Buratowski S, Emili A, et al. 2004. Proteasome involvement in the repair of DNA doublestrand breaks. Mol Cell 16: 1027-1034.

Kurumizaka H, Ikawa S, Nakada M, Eda K, Kagawa W, Takata M, Takeda S, Yokoyama S, Shibata T. 2001. Homologous-pairing activity of the human DNA-repair proteins Xrcc3.Rad51C. Proc Natl Acad Sci 98: 55385543.

Kurumizaka H, Ikawa S, Nakada M, Enomoto R, Kagawa W, Kinebuchi T, Yamazoe M, Yokoyama S, Shibata T. 2002. Homologous pairing and ring and filament structure formation activities of the human Xrcc2-Rad51D complex. J Biol Chem 277: 14315-14320.

Kurumizaka H, Enomoto R, Nakada M, Eda K, Yokoyama S, Shibata T. 2003. Region and amino acid residues required for Rad51C binding in the human Xrcc3 protein. Nucleic Acids Res 31: 4041-4050.

Kuznetsov S, Pellegrini M, Shuda K, Fernandez-Capetillo O, Liu Y, Martin BK, Burkett S, Southon E, Pati D, Tessarollo L, et al. 2007. RAD51C deficiency in mice results in early prophase I arrest in males and sister chromatid separation at metaphase II in females. J Cell Biol 176: 581-592.

Kuznetsov SG, Liu P, Sharan SK. 2008. Mouse embryonic stem cell-based functional assay to evaluate mutations in BRCA2. Nat Med 14: 875-881.

Kuznetsov SG, Haines DC, Martin BK, Sharan SK. 2009. Loss of Rad51c leads to embryonic lethality and modulation of Trp53-dependent tumorigenesis in mice. Cancer Res 69: 863-872.

* Lam I, Keeney S. 2015. Mechanism and regulation of meiotic recombination initiation. Cold Spring Harb Perspect Biol 7: a016634.

Laufer M, Nandula SV, Modi AP, Wang S, Jasin M, Murty VV, Ludwig T, Baer R. 2007. Structural requirements for the BARD1 tumor suppressor in chromosomal stability and homology-directed DNA repair. J Biol Chem 282: 34325-34333.

Lee Y, McKinnon PJ. 2002. DNA ligase IV suppresses medulloblastoma formation. Cancer Res 62: 6395-6399. 
R. Prakash et al.

Lee MS, Green R, Marsillac SM, Coquelle N, Williams RS, Yeung T, Foo D, Hau DD, Hui B, Monteiro AN, et al. 2010. Comprehensive analysis of missense variations in the BRCT domain of BRCA1 by structural and functional assays. Cancer Res 70: 4880-4890.

Levitus M, Waisfisz Q, Godthelp BC, de Vries Y, Hussain S, Wiegant WW, Elghalbzouri-Maghrani E, Steltenpool J, Rooimans MA, Pals G, et al. 2005. The DNA helicase BRIP1 is defective in Fanconi anemia complementation group J. Nat Genet 37: 934-935.

Levran O, Attwooll C, Henry RT, Milton KL, Neveling K, Rio P, Batish SD, Kalb R, Velleuer E, Barral S, et al. 2005. The BRCA1-interacting helicase BRIP1 is deficient in Fanconi anemia. Nat Genet 37: 931-933.

Li ML, Greenberg RA. 2012. Links between genome integrity and BRCA1 tumor suppression. Trends Biochem Sci 37: $418-424$.

Li J, Zou C, Bai Y, Wazer DE, Band V, Gao Q. 2006. DSS1 is required for the stability of BRCA2. Oncogene 25: 11861194.

Liang F, Han M, Romanienko PJ, Jasin M. 1998. Homologydirected repair is a major double-strand break repair pathway in mammalian cells. Proc Natl Acad Sci 95: 5172-5177.

Lim DS, Hasty P. 1996. A mutation in mouse rad51 results in an early embryonic lethal that is suppressed by a mutation in p53. Mol Cell Biol 16: 7133-7143.

Lio YC, Mazin AV, Kowalczykowski SC, Chen DJ. 2003. Complex formation by the human Rad51B and Rad51C DNA repair proteins and their activities in vitro. J Biol Chem 278: 2469-2478.

Litman R, Peng M, Jin Z, Zhang F, Zhang J, Powell S, Andreassen PR, Cantor SB. 2005. BACH1 is critical for homologous recombination and appears to be the Fanconi anemia gene product FANCJ. Cancer Cell 8: 255-265.

Liu N, Lamerdin JE, Tebbs RS, Schild D, Tucker JD, Shen MR, Brookman KW, Siciliano MJ, Walter CA, Fan W, et al. 1998. XRCC2 and XRCC3, new human Rad51-family members, promote chromosome stability and protect against DNA cross-links and other damages. Mol Cell 1: 783-793.

Liu N, Schild D, Thelen MP, Thompson LH. 2002. Involvement of Rad51C in two distinct protein complexes of Rad51 paralogs in human cells. Nucleic Acids Res 30: 1009-1015.

Liu Y, Masson JY, Shah R, O'Regan P, West SC. 2004. RAD51C is required for Holliday junction processing in mammalian cells. Science 303: 243-246.

Liu J, Doty T, Gibson B, Heyer WD. 2010. Human BRCA2 protein promotes RAD51 filament formation on RPAcovered single-stranded DNA. Nat Struct Mol Biol 17: 1260-1262.

Lomonosov M, Anand S, Sangrithi M, Davies R, Venkitaraman AR. 2003. Stabilization of stalled DNA replication forks by the BRCA2 breast cancer susceptibility protein. Genes Dev 17: 3017-3022.

London TB, Barber LJ, Mosedale G, Kelly GP, Balasubramanian S, Hickson ID, Boulton SJ, Hiom K. 2008. FANCJ is a structure-specific DNA helicase associated with the maintenance of genomic G/C tracts. J Biol Chem 283: $36132-36139$.
Long DT, Raschle M, Joukov V, Walter JC. 2011. Mechanism of RAD51-dependent DNA interstrand cross-link repair. Science 333: 84-87.

Loveday C, Turnbull C, Ramsay E, Hughes D, Ruark E, Frankum JR, Bowden G, Kalmyrzaev B, Warren-Perry M, Snape K, et al. 2011. Germline mutations in RAD51D confer susceptibility to ovarian cancer. Nat $\mathrm{Ge}$ net 43: 879-882.

Loveday C, Turnbull C, Ruark E, Xicola RM, Ramsay E, Hughes D, Warren-Perry M, Snape K, Eccles D, Evans DG, et al. 2012. Germline RAD51C mutations confer susceptibility to ovarian cancer. Nat Genet 44: 475476; author reply 476

Ludwig T, Chapman DL, Papaioannou VE, Efstratiadis A. 1997. Targeted mutations of breast cancer susceptibility gene homologs in mice: Lethal phenotypes of Brcal, Brca2, Brca1/Brca2, Brca1/p53, and Brca2/p53 nullizygous embryos. Genes Dev 11: 1226-1241.

Mali P, Yang L, Esvelt KM, Aach J, Guell M, DiCarlo JE, Norville JE, Church GM. 2013. RNA-guided human genome engineering via Cas9. Science 339: 823-826.

Marston NJ, Richards WJ, Hughes D, Bertwistle D, Marshall CJ, Ashworth A. 1999. Interaction between the product of the breast cancer susceptibility gene BRCA2 and DSS1, a protein functionally conserved from yeast to mammals. Mol Cell Biol 19: 4633-4642.

Masson JY, Tarsounas MC, Stasiak AZ, Stasiak A, Shah R, McIlwraith MJ, Benson FE, West SC. 2001. Identification and purification of two distinct complexes containing the five RAD51 paralogs. Genes Dev 15: 3296-3307.

McCabe N, Turner NC, Lord CJ, Kluzek K, Bialkowska A, Swift S, Giavara S, O'Connor MJ, Tutt AN, Zdzienicka MZ, et al. 2006. Deficiency in the repair of DNA damage by homologous recombination and sensitivity to poly(ADP-ribose) polymerase inhibition. Cancer Res 66: 8109-8115.

McCarthy EE, Celebi JT, Baer R, Ludwig T. 2003. Loss of Bard1, the heterodimeric partner of the Brcal tumor suppressor, results in early embryonic lethality and chromosomal instability. Mol Cell Biol 23: 5056-5063.

* Mehta A, Haber JE. 2014. Sources of DNA double-strand breaks and models of recombinational DNA repair. Cold Spring Harb Perspect Biol 6: a016428.

Meindl A, Hellebrand H, Wiek C, Erven V, Wappenschmidt B, Niederacher D, Freund M, Lichtner P, Hartmann L, Schaal H, et al. 2010. Germline mutations in breast and ovarian cancer pedigrees establish $R A D 51 C$ as a human cancer susceptibility gene. Nat Genet 42: 410-414.

Metcalfe K, Lubinski J, Lynch HT, Ghadirian P, Foulkes WD, Kim-Sing C, Neuhausen S, Tung N, Rosen B, Gronwald J, et al. 2010. Family history of cancer and cancer risks in women with BRCA1 or BRCA2 mutations. J Natl Cancer Inst 102: 1874-1878.

Meyer S, Tischkowitz M, Chandler K, Gillespie A, Birch JM, Evans DG. 2014. Fanconi anaemia, BRCA2 mutations and childhood cancer: A developmental perspective from clinical and epidemiological observations with implications for genetic counselling. J Med Genet 51: 71-75.

Miki Y, Swensen J, Shattuck-Eidens D, Futreal PA, Harshman K, Tavtigian S, Liu Q, Cochran C, Bennett LM, Ding W, et al. 1994. A strong candidate for the breast and 
ovarian cancer susceptibility gene BRCA1. Science 266: $66-71$.

Miller KA, Sawicka D, Barsky D, Albala JS. 2004. Domain mapping of the Rad51 paralog protein complexes. $\mathrm{Nu}$ cleic Acids Res 32: 169-178.

Mills KD, Ferguson DO, Essers J, Eckersdorff M, Kanaar R, Alt FW. 2004. Rad54 and DNA Ligase IV cooperate to maintain mammalian chromatid stability. Genes Dev 18: $1283-1292$.

Min A, Im SA, Yoon YK, Song SH, Nam HJ, Hur HS, Kim HP, Lee KH, Han SW, Oh DY, et al. 2013. RAD51C-deficient cancer cells are highly sensitive to the PARP inhibitor olaparib. Mol Cancer Ther 12: 865-877.

Mizuta R, LaSalle JM, Cheng HL, Shinohara A, Ogawa H, Copeland N, Jenkins NA, Lalande M, Alt FW. 1997. RAB22 and RAB163/mouse BRCA2: Proteins that specifically interact with the RAD51 protein. Proc Natl Acad Sci 94: 6927-6932.

Moldovan GL, D’Andrea AD. 2009. How the Fanconi anemia pathway guards the genome. Annu Rev Genet 43 223-249.

* Morrical SW. 2015. DNA pairing and annealing processes in homologous recombination and homology-directed repair. Cold Spring Harb Perspect Biol 7: a016444.

Morris JR, Solomon E. 2004. BRCA1: BARD1 induces the formation of conjugated ubiquitin structures, dependent on K6 of ubiquitin, in cells during DNA replication and repair. Hum Mol Genet 13: 807-817.

Moynahan ME. 2002. The cancer connection: BRCA1 and BRCA2 tumor suppression in mice and humans. Oncogene 21: 8994-9007.

Moynahan ME, Jasin M. 2010. Mitotic homologous recombination maintains genomic stability and suppresses tumorigenesis. Nat Rev Mol Cell Biol 11: 196-207.

Moynahan ME, Chiu JW, Koller BH, Jasin M. 1999. Brcal controls homology-directed DNA repair. Mol Cell 4: 511-518.

Moynahan ME, Cui TY, Jasin M. 2001a. Homology-directed DNA repair, mitomycin-c resistance, and chromosome stability is restored with correction of a Brcal mutation. Cancer Res 61: 4842-4850.

Moynahan ME, Pierce AJ, Jasin M. 2001b. BRCA2 is required for homology-directed repair of chromosomal breaks. Mol Cell 7: 263-272.

Nakanishi K, Yang YG, Pierce AJ, Taniguchi T, Digweed M, D’Andrea AD, Wang ZQ, Jasin M. 2005. Human Fanconi anemia monoubiquitination pathway promotes homologous DNA repair. Proc Natl Acad Sci 102: 1110-1115.

Nakanishi K, Cavallo F, Perrouault L, Giovannangeli C, Moynahan ME, Barchi M, Brunet E, Jasin M. 2011. Homology-directed Fanconi anemia pathway cross-link repair is dependent on DNA replication. Nat Struct Mol Biol 18: 500-503.

Nicodeme F, Geffroy S, Conti M, Delobel B, Soenen V, Grardel N, Porte H, Copin MC, Lai JL, Andrieux J. 2005. Familial occurrence of thymoma and autoimmune diseases with the constitutional translocation t(14;20)(q24.1;p12.3). Genes Chrom Cancer 44: 154160.

Nishikawa H, Ooka S, Sato K, Arima K, Okamoto J, Klevit RE, Fukuda M, Ohta T. 2004. Mass spectrometric and mutational analyses reveal Lys-6-linked polyubiquitin chains catalyzed by BRCA1-BARD1 ubiquitin ligase. $J$ Biol Chem 279: 3916-3924.

Oliver AW, Swift S, Lord CJ, Ashworth A, Pearl LH. 2009. Structural basis for recruitment of BRCA2 by PALB2. EMBO Rep 10: 990-996.

O'Regan P, Wilson C, Townsend S, Thacker J. 2001. XRCC2 is a nuclear RAD51-like protein required for damagedependent RAD51 focus formation without the need for ATP binding. J Biol Chem 276: 22148-22153.

Orii KE, Lee Y, Kondo N, McKinnon PJ. 2006. Selective utilization of nonhomologous end-joining and homologous recombination DNA repair pathways during nervous system development. Proc Natl Acad Sci 103: 10017-10022.

Ozcelik H, Schmocker B, Di Nicola N, Shi XH, Langer B, Moore M, Taylor BR, Narod SA, Darlington G, Andrulis IL, et al. 1997. Germline BRCA2 6174delT mutations in Ashkenazi Jewish pancreatic cancer patients. Nat Genet 16: $17-18$.

Park DJ, Lesueur F, Nguyen-Dumont T, Pertesi M, Odefrey F, Hammet F, Neuhausen SL, John EM, Andrulis IL, Terry $\mathrm{MB}$, et al. 2012. Rare mutations in XRCC2 increase the risk of breast cancer. Am J Hum Genet 90: 734-739.

Pellegrini L, Yu DS, Lo T, Anand S, Lee M, Blundell TL, Venkitaraman AR. 2002. Insights into DNA recombination from the structure of a RAD51-BRCA2 complex. Nature 420: 287-293.

Pennington KP, Walsh T, Harrell MI, Lee MK, Pennil CC, Rendi MH, Thornton A, Norquist BM, Casadei S, Nord AS, et al. 2014. Germline and somatic mutations in homologous recombination genes predict platinum response and survival in ovarian, fallopian tube, and peritoneal carcinomas. Clin Cancer Res 20: 764-775.

Pierce AJ, Johnson RD, Thompson LH, Jasin M. 1999. XRCC3 promotes homology-directed repair of DNA damage in mammalian cells. Genes Dev 13: 2633-2638.

Pierce AJ, Hu P, Han M, Ellis N, Jasin M. 2001. Ku DNA endbinding protein modulates homologous repair of double-strand breaks in mammalian cells. Genes Dev 15: 3237-3242.

Pittman DL, Schimenti JC. 2000. Midgestation lethality in mice deficient for the RecA-related gene, Rad51d/ Rad5113. Genesis 26: 167-173.

Pittman DL, Weinberg LR, Schimenti JC. 1998. Identification, characterization, and genetic mapping of Rad51d, a new mouse and human RAD51/RecA-related gene. Genomics 49: 103-111.

Proia TA, Keller PJ, Gupta PB, Klebba I, Jones AD, Sedic M, Gilmore H, Tung N, Naber SP, Schnitt S, et al. 2011. Genetic predisposition directs breast cancer phenotype by dictating progenitor cell fate. Cell Stem Cell 8: 149163.

Rafnar T, Gudbjartsson DF, Sulem P, Jonasdottir A, Sigurdsson A, Jonasdottir A, Besenbacher S, Lundin P, Stacey SN, Gudmundsson J, et al. 2011. Mutations in BRIP1 confer high risk of ovarian cancer. Nat Genet 43: 1104-1107.

Rahman N, Seal S, Thompson D, Kelly P, Renwick A, Elliott A, Reid S, Spanova K, Barfoot R, Chagtai T, et al. 2007. PALB2, which encodes a BRCA2-interacting protein, is a breast cancer susceptibility gene. Nat Genet 39: 165-167. 
R. Prakash et al.

Ratajska M, Antoszewska E, Piskorz A, Brozek I, Borg A Kusmierek H, Biernat W, Limon J. 2012. Cancer predisposing BARD1 mutations in breast-ovarian cancer families. Breast Cancer Res Treat 131: 89-97.

* Reams AB, Roth JR. 2015. Mechanisms of gene duplication and amplification. Cold Spring Harb Perspect Biol 7: a016592.

Reczek CR, Szabolcs M, Stark JM, Ludwig T, Baer R. 2013. The interaction between CtIP and BRCA1 is not essential for resection-mediated DNA repair or tumor suppression. J Cell Biol 201: 693-707.

Reid S, Schindler D, Hanenberg H, Barker K, Hanks S, Kalb R, Neveling K, Kelly P, Seal S, Freund M, et al. 2007. Biallelic mutations in PALB2 cause Fanconi anemia subtype FA-N and predispose to childhood cancer. Nat Genet 39: $162-164$.

Reid LJ, Shakya R, Modi AP, Lokshin M, Cheng JT, Jasin M, Baer R, Ludwig T. 2008. E3 ligase activity of BRCA1 is not essential for mammalian cell viability or homology-directed repair of double-strand DNA breaks. Proc Natl Acad Sci 105: 20876-20881.

Richardson C, Jasin M. 2000. Coupled homologous and nonhomologous repair of a double-strand break preserves genomic integrity in mammalian cells. Mol Cell Biol 20: 9068-9075.

Rijkers T, Van Den Ouweland J, Morolli B, Rolink AG, Baarends WM, Van Sloun PP, Lohman PH, Pastink A. 1998 Targeted inactivation of mouse RAD52 reduces homologous recombination but not resistance to ionizing radiation. Mol Cell Biol 18: 6423-6429.

Rodrigue A, Coulombe Y, Jacquet K, Gagne JP, Roques C, Gobeil S, Poirier G, Masson JY. 2013. The RAD51 paralogs ensure cellular protection against mitotic defects and aneuploidy. J Cell Sci 126: 348-359.

Rothkamm K, Kruger I, Thompson LH, Lobrich M. 2003. Pathways of DNA double-strand break repair during the mammalian cell cycle. Mol Cell Biol 23: 5706-5715.

Rouet P, Smih F, Jasin M. 1994. Introduction of doublestrand breaks into the genome of mouse cells by expression of a rare-cutting endonuclease. Mol Cell Biol 14: 8096-8106.

Ruffner H, Joazeiro CA, Hemmati D, Hunter T, Verma IM. 2001. Cancer-predisposing mutations within the RING domain of BRCA1: Loss of ubiquitin protein ligase activity and protection from radiation hypersensitivity. Proc Natl Acad Sci 98: 5134-5139.

Sabatier R, Adelaide J, Finetti P, Ferrari A, Huiart L, Sobol H, Chaffanet M, Birnbaum D, Bertucci F. 2010. BARD1 homozygous deletion, a possible alternative to BRCA1 mutation in basal breast cancer. Genes Chrom Cancer 49: 1143-1151.

Saeki H, Siaud N, Christ N, Wiegant WW, van Buul PP, Han M, Zdzienicka MZ, Stark JM, Jasin M. 2006. Suppression of the DNA repair defects of BRCA2-deficient cells with heterologous protein fusions. Proc Natl Acad Sci 103: 8768-8773.

Sartori AA, Lukas C, Coates J, Mistrik M, Fu S, Bartek J, Baer R, Lukas J, Jackson SP. 2007. Human CtIP promotes DNA end resection. Nature 450: 509-514.

Sawyer SL, Tian L, Kahkonen M, Schwartzentruber J, Kircher M, Majewski J, Dyment DA, Innes AM, Boycott KM, Moreau LA, et al. 2015. Biallelic mutations in
BRCA1 cause a new Fanconi anemia subtype. Cancer Discov 5: 135-142.

Schild D, Lio YC, Collins DW, Tsomondo T, Chen DJ. 2000. Evidence for simultaneous protein interactions between human Rad51 paralogs. J Biol Chem 275: 16443-16449.

Schlacher K, Christ N, Siaud N, Egashira A, Wu H, Jasin M. 2011. Double-strand break repair-independent role for BRCA2 in blocking stalled replication fork degradation by MRE11. Cell 145: 529-542.

Schlacher K, Wu H, Jasin M. 2012. A distinct replication fork protection pathway connects Fanconi anemia tumor suppressors to RAD51-BRCA1/2. Cancer Cell 22: 106-116.

Schoenmakers EF, Huysmans C, Van de Ven WJ. 1999. Allelic knockout of novel splice variants of human recombination repair gene $R A D 51 B$ in $\mathrm{t}(12 ; 14)$ uterine leiomyomas. Cancer Res 59: 19-23.

Scully R, Chen J, Plug A, Xiao Y, Weaver D, Feunteun J, Ashley T, Livingston DM. 1997. Association of BRCA1 with Rad51 in mitotic and meiotic cells. Cell 88: 265275.

Seal S, Thompson D, Renwick A, Elliott A, Kelly P, Barfoot R, Chagtai T, Jayatilake H, Ahmed M, Spanova K, et al. 2006. Truncating mutations in the Fanconi anemia J gene BRIP1 are low-penetrance breast cancer susceptibility alleles. Nat Genet 38: 1239-1241.

Shakya R, Szabolcs M, McCarthy E, Ospina E, Basso K, Nandula S, Murty V, Baer R, Ludwig T. 2008. The basal-like mammary carcinomas induced by Brcal or Bard1 inactivation implicate the BRCA1/BARD1 heterodimer in tumor suppression. Proc Natl Acad Sci 105: 7040-7045.

Shakya R, Reid LJ, Reczek CR, Cole F, Egli D, Lin CS, deRooij DG, Hirsch S, Ravi K, Hicks JB, et al. 2011. BRCA1 tumor suppression depends on BRCT phosphoprotein binding, but not its E3 ligase activity. Science 334: 525-528.

Shamseldin HE, Elfaki M, Alkuraya FS. 2012. Exome sequencing reveals a novel Fanconi group defined by XRCC2 mutation. J Med Genet 49: 184-186.

Sharan SK, Morimatsu M, Albrecht U, Lim DS, Regel E, Dinh C, Sands A, Eichele G, Hasty P, Bradley A. 1997. Embryonic lethality and radiation hypersensitivity mediated by Rad51 in mice lacking Brca2. Nature 386: $804-$ 810.

Shim KS, Schmutte C, Tombline G, Heinen CD, Fishel R. 2004. hXRCC2 enhances ADP/ATP processing and strand exchange by hRAD51. J Biol Chem 279: 3038530394.

Shin DS, Pellegrini L, Daniels DS, Yelent B, Craig L, Bates D, Yu DS, Shivji MK, Hitomi C, Arvai AS, et al. 2003. Fulllength archaeal Rad51 structure and mutants: Mechanisms for RAD51 assembly and control by BRCA2. EMBO J 22: 4566-4576.

Shu Z, Smith S, Wang L, Rice MC, Kmiec EB. 1999. Disruption of $\mu R E C 2 / R A D 51 L 1$ in mice results in early embryonic lethality which can be partially rescued in a p53 - - background. Mol Cell Biol 19: 8686-8693.

Siaud N, Barbera MA, Egashira A, Lam I, Christ N, Schlacher K, Xia B, Jasin M. 2011. Plasticity of BRCA2 function in homologous recombination: Genetic interactions of the PALB2 and DNA binding domains. PLoS Genet 7: e1002409. 
Sigurdsson S, Van Komen S, Bussen W, Schild D, Albala JS, Sung P. 2001. Mediator function of the human Rad51BRad51C complex in Rad51/RPA-catalyzed DNA strand exchange. Genes Dev 15: 3308-3318.

Skoulidis F, Cassidy LD, Pisupati V, Jonasson JG, Bjarnason H, Eyfjord JE, Karreth FA, Lim M, Barber LM, Clatworthy SA, et al. 2010. Germline Brca2 heterozygosity promotes $\operatorname{Kras}(\mathrm{G} 12 \mathrm{D})$-driven carcinogenesis in a murine model of familial pancreatic cancer. Cancer Cell 18: 499-509.

Smeenk G, de Groot AJ, Romeijn RJ, van Buul PP, Zdzienicka MZ, Mullenders LH, Pastink A, Godthelp BC. 2010. Rad51C is essential for embryonic development and haploinsufficiency causes increased DNA damage sensitivity and genomic instability. Mutat Res 689: 5058.

Smiraldo PG, Gruver AM, Osborn JC, Pittman DL. 2005. Extensive chromosomal instability in Rad51d-deficient mouse cells. Cancer Res 65: 2089-2096.

Sobhian B, Shao G, Lilli DR, Culhane AC, Moreau LA, Xia B, Livingston DM, Greenberg RA. 2007. RAP80 targets BRCA1 to specific ubiquitin structures at DNA damage sites. Science 316: 1198-1202.

Somyajit K, Subramanya S, Nagaraju G. 2012. Distinct roles of FANCO/RAD51C protein in DNA damage signaling and repair: Implications for Fanconi anemia and breast cancer susceptibility. J Biol Chem 287: 3366-3380.

Stark JM, Hu P, Pierce AJ, Moynahan ME, Ellis N, Jasin M. 2002. ATP hydrolysis by mammalian RAD51 has a key role during homology-directed DNA repair. J Biol Chem 277: 20185-20194.

Stark JM, Pierce AJ, Oh J, Pastink A, Jasin M. 2004. Genetic steps of mammalian homologous repair with distinct mutagenic consequences. Mol Cell Biol 24: 9305-9316.

Suzuki A, de la Pompa JL, Hakem R, Elia A, Yoshida R, Mo R, Nishina H, Chuang T, Wakeham A, Itie A, et al. 1997. $\mathrm{Brca} 2$ is required for embryonic cellular proliferation in the mouse. Genes Dev 11: 1242-1252.

Sy SM, Huen MS, Chen J. 2009. PALB2 is an integral component of the BRCA complex required for homologous recombination repair. Proc Natl Acad Sci 106: 71557160.

* Syeda AH, Hawkins M, McGlynn P. 2014. Recombination and replication. Cold Spring Harb Perspect Biol 6: a016550.

* Symington LS. 2014. End resection at DNA double-strand breaks: Mechanism and regulation. Cold Spring Harb Perspect Biol 6: a016436.

Takata M, Sasaki MS, Tachiiri S, Fukushima T, Sonoda E, Schild D, Thompson LH, Takeda S. 2001. Chromosome instability and defective recombinational repair in knockout mutants of the five Rad51 paralogs. Mol Cell Biol 21: 2858-2866.

Tang J, Cho NW, Cui G, Manion EM, Shanbhag NM, Botuyan MV, Mer G, Greenberg RA. 2013. Acetylation limits 53BP1 association with damaged chromatin to promote homologous recombination. Nat Struct Mol Biol 20: 317-325.

Tarsounas M, Munoz P, Claas A, Smiraldo PG, Pittman DL, Blasco MA, West SC. 2004. Telomere maintenance requires the RAD51D recombination/repair protein. Cell 117: $337-347$.
Tavtigian SV, Simard J, Rommens J, Couch F, Shattuck-Eidens D, Neuhausen S, Merajver S, Thorlacius S, Offit K, Stoppa-Lyonnet D, et al. 1996. The complete BRCA2 gene and mutations in chromosome 13q-linked kindreds. Nat Genet 12: 333-337.

Tebbs RS, Zhao Y, Tucker JD, Scheerer JB, Siciliano MJ, Hwang M, Liu N, Legerski RJ, Thompson LH. 1995. Correction of chromosomal instability and sensitivity to diverse mutagens by a cloned cDNA of the XRCC3 DNA repair gene. Proc Natl Acad Sci 92: 6354-6358.

Thorslund T, Esashi F, West SC. 2007. Interactions between human BRCA2 protein and the meiosis-specific recombinase DMC1. EMBO J 26: 2915-2922.

Thorslund T, McIlwraith MJ, Compton SA, Lekomtsev S, Petronczki M, Griffith JD, West SC. 2010. The breast cancer tumor suppressor BRCA2 promotes the specific targeting of RAD51 to single-stranded DNA. Nat Struct Mol Biol 17: 1263-1265.

Tischkowitz M, Xia B. 2010. PALB2/FANCN: Recombining cancer and Fanconi anemia. Cancer Res 70: 7353-7359.

Tischkowitz M, Xia B, Sabbaghian N, Reis-Filho JS, Hamel N, Li G, van Beers EH, Li L, Khalil T, Quenneville LA, et al. 2007. Analysis of PALB2/FANCN-associated breast cancer families. Proc Natl Acad Sci 104: 6788-6793.

Towler WI, Zhang J, Ransburgh DJ, Toland AE, Ishioka C, Chiba N, Parvin JD. 2013. Analysis of BRCA1 variants in double-strand break repair by homologous recombination and single-strand annealing. Hum Mutat 34: 439445.

Tsuzuki T, Fujii Y, Sakumi K, Tominaga Y, Nakao K, Sekiguchi M, Matsushiro A, Yoshimura Y, Morita T. 1996 Targeted disruption of the Rad51 gene leads to lethality in embryonic mice. Proc Natl Acad Sci 93: 6236-6240.

Tutt A, Gabriel A, Bertwistle D, Connor F, Paterson H, Peacock J, Ross G, Ashworth A. 1999. Absence of Brca2 causes genome instability by chromosome breakage and loss associated with centrosome amplification. Curr Biol 9: $1107-1110$.

Tutt A, Bertwistle D, Valentine J, Gabriel A, Swift S, Ross G, Griffin C, Thacker J, Ashworth A. 2001. Mutation in Brca2 stimulates error-prone homology-directed repair of DNA double-strand breaks occurring between repeated sequences. EMBO J 20: 4704-4716.

Urbin SS, Elvers I, Hinz JM, Helleday T, Thompson LH. 2012. Uncoupling of RAD51 focus formation and cell survival after replication fork stalling in RAD51D null CHO cells. Environ Mol Mutagen 53: 114-124.

van Asperen CJ, Brohet RM, Meijers-Heijboer EJ, Hoogerbrugge N, Verhoef S, Vasen HF, Ausems MG, Menko FH, Gomez Garcia EB, Klijn JG, et al. 2005. Cancer risks in BRCA2 families: Estimates for sites other than breast and ovary. J Med Genet 42: 711-719.

Vaz F, Hanenberg H, Schuster B, Barker K, Wiek C, Erven V, Neveling K, Endt D, Kesterton I, Autore F, et al. 2010. Mutation of the RAD51C gene in a Fanconi anemialike disorder. Nat Genet 42: 406-409.

Venkitaraman AR. 2014. Cancer suppression by the chromosome custodians, BRCA1 and BRCA2. Science 343: 1470-1475.

Waddell N, Arnold J, Cocciardi S, da Silva L, Marsh A, Riley J, Johnstone CN, Orloff M, Assie G, Eng C, et al. 2010 
R. Prakash et al.

Subtypes of familial breast tumours revealed by expression and copy number profiling. Breast Canc Res Treat 123: 661-677.

Walsh T, Casadei S, Lee MK, Pennil CC, Nord AS, Thornton AM, Roeb W, Agnew KJ, Stray SM, Wickramanayake A, et al. 2011. Mutations in 12 genes for inherited ovarian, fallopian tube, and peritoneal carcinoma identified by massively parallel sequencing. Proc Natl Acad Sci 108: 18032-18037.

Wang B, Elledge SJ. 2007. Ubc13/Rnf8 ubiquitin ligases control foci formation of the Rap80/Abraxas/Brcal/ Brcc36 complex in response to DNA damage. Proc Natl Acad Sci 104: 20759-20763.

Wang B, Matsuoka S, Ballif BA, Zhang D, Smogorzewska A, Gygi SP, Elledge SJ. 2007. Abraxas and RAP80 form a BRCA1 protein complex required for the DNA damage response. Science 316: 1194-1198.

Westermark UK, Reyngold M, Olshen AB, Baer R, Jasin M, Moynahan ME. 2003. BARD1 participates with BRCA1 in homology-directed repair of chromosome breaks. $\mathrm{Mol}$ Cell Biol 23: 7926-7936.

Wiese C, Collins DW, Albala JS, Thompson LH, Kronenberg A, Schild D. 2002. Interactions involving the Rad51 paralogs Rad51C and XRCC3 in human cells. Nucleic Acids Res 30: 1001-1008.

Wiese C, Hinz JM, Tebbs RS, Nham PB, Urbin SS, Collins DW, Thompson LH, Schild D. 2006. Disparate requirements for the Walker A and B ATPase motifs of human RAD51D in homologous recombination. Nucleic Acids Res 34: 2833-2843.

Williams RS, Glover JN. 2003. Structural consequences of a cancer-causing BRCA1-BRCT missense mutation. J Biol Chem 278: 2630-2635.

Williams RS, Chasman DI, Hau DD, Hui B, Lau AY, Glover JN. 2003. Detection of protein folding defects caused by BRCA1-BRCT truncation and missense mutations. J Biol Chem 278: 53007-53016.

Wong AK, Pero R, Ormonde PA, Tavtigian SV, Bartel PL. 1997. RAD51 interacts with the evolutionarily conserved BRC motifs in the human breast cancer susceptibility gene brca2. J Biol Chem 272: 31941-31944.

Wong AK, Ormonde PA, Pero R, Chen Y, Lian L, Salada G, Berry S, Lawrence Q, Dayananth P, Ha P, et al. 1998. Characterization of a carboxy-terminal BRCA1 interacting protein. Oncogene 17: 2279-2285.

Wooster R, Bignell G, Lancaster J, Swift S, Seal S, Mangion J, Collins N, Gregory S, Gumbs C, Micklem G. 1995. Identification of the breast cancer susceptibility gene BRCA2. Nature 378: 789-792.

Wu LC, Wang ZW, Tsan JT, Spillman MA, Phung A, Xu XL, Yang MC, Hwang LY, Bowcock AM, Baer R. 1996. Identification of a RING protein that can interact in vivo with the BRCA1 gene product. Nat Genet 14: 430-440.

Wu Y, Shin-ya K, Brosh RM Jr. 2008. FANCJ helicase defective in Fanconia anemia and breast cancer unwinds Gquadruplex DNA to defend genomic stability. Mol Cell Biol 28: 4116-4128.

Wu-Baer F, Lagrazon K, Yuan W, Baer R. 2003. The BRCA1/ BARD1 heterodimer assembles polyubiquitin chains through an unconventional linkage involving lysine residue K6 of ubiquitin. J Biol Chem 278: 34743-34746.
* Wyatt HDM, West SC. 2014. Holliday junction resolvases. Cold Spring Harb Perspect Biol 6: a023192.

Xia F, Taghian DG, DeFrank JS, Zeng ZC, Willers H, Iliakis G, Powell SN. 2001. Deficiency of human BRCA2 leads to impaired homologous recombination but maintains normal nonhomologous end joining. Proc Natl Acad Sci 98: 8644-8649.

Xia B, Sheng Q, Nakanishi K, Ohashi A, Wu J, Christ N, Liu X, Jasin M, Couch FJ, Livingston DM. 2006. Control of BRCA2 cellular and clinical functions by a nuclear partner, PALB2. Mol Cell 22: 719-729.

Xia B, Dorsman JC, Ameziane N, de Vries Y, Rooimans MA, Sheng Q, Pals G, Errami A, Gluckman E, Llera J, et al. 2007. Fanconi anemia is associated with a defect in the BRCA2 partner PALB2. Nat Genet 39: 159-161.

Yamada NA, Hinz JM, Kopf VL, Segalle KD, Thompson LH. 2004. XRCC3 ATPase activity is required for normal XRCC3-Rad51C complex dynamics and homologous recombination. J Biol Chem 279: 23250-23254.

Yang H, Jeffrey PD, Miller J, Kinnucan E, Sun Y, Thoma NH, Zheng N, Chen PL, Lee WH, Pavletich NP. 2002. BRCA2 function in DNA binding and recombination from a BRCA2-DSS1-ssDNA structure. Science 297: $1837-1848$.

Yang H, Li Q, Fan J, Holloman WK, Pavletich NP. 2005. The BRCA2 homologue Brh2 nucleates RAD51 filament formation at a dsDNA-ssDNA junction. Nature 433: 653657.

Yokoyama H, Kurumizaka H, Ikawa S, Yokoyama S, Shibata T. 2003. Holliday junction binding activity of the human Rad51B protein. J Biol Chem 278: 2767-2772.

Yokoyama H, Sarai N, Kagawa W, Enomoto R, Shibata T, Kurumizaka H, Yokoyama S. 2004. Preferential binding to branched DNA strands and strand-annealing activity of the human Rad51B, Rad51C, Rad51D, and Xrcc2 protein complex. Nucleic Acids Res 32: $2556-2565$.

Yonetani Y, Hochegger H, Sonoda E, Shinya S, Yoshikawa H, Takeda S, Yamazoe M. 2005. Differential and collaborative actions of Rad51 paralog proteins in cellular response to DNA damage. Nucleic Acids Res 33: 4544-4552.

Yoshihara T, Ishida M, Kinomura A, Katsura M, Tsuruga T, Tashiro S, Asahara T, Miyagawa K. 2004. XRCC3 deficiency results in a defect in recombination and increased endoreduplication in human cells. EMBO J 23: 670-680.

Yu X, Chen J. 2004. DNA damage-induced cell cycle checkpoint control requires CtIP, a phosphorylation-dependent binding partner of BRCA1 C-terminal domains. Mol Cell Biol 24: 9478-9486.

Yu X, Wu LC, Bowcock AM, Aronheim A, Baer R. 1998. The C-terminal (BRCT) domains of BRCA1 interact in vivo with CtIP, a protein implicated in the CtBP pathway of transcriptional repression. J Biol Chem 273: 2538825392.

Yu DS, Sonoda E, Takeda S, Huang CL, Pellegrini L, Blundell TL, Venkitaraman AR. 2003a. Dynamic control of Rad51 recombinase by self-association and interaction with BRCA2. Mol Cell 12: 1029-1041. 
HR Proteins Linked to Human Disease

Yu X, Chini CC, He M, Mer G, Chen J. 2003b. The BRCT domain is a phospho-protein binding domain. Science 302: 639-642.

Yu X, Fu S, Lai M, Baer R, Chen J. 2006. BRCA1 ubiquitinates its phosphorylation-dependent binding partner CtIP. Genes Dev 20: 1721-1726.

Yun MH, Hiom K. 2009. CtIP-BRCA1 modulates the choice of DNA double-strand-break repair pathway throughout the cell cycle. Nature 459: 460-463.

* Zelensky A, Kanaar R, Wyman C. 2014. Mediators of homologous DNA pairing. Cold Spring Harb Perspect Biol 6: $\mathrm{a} 016451$.

Zhang F, Fan Q, Ren K, Andreassen PR. 2009a. PALB2 functionally connects the breast cancer susceptibility proteins BRCA1 and BRCA2. Mol Cancer Res 7: 11101118.

Zhang F, Ma J, Wu J, Ye L, Cai H, Xia B, Yu X. 2009b. PALB2 links BRCA1 and BRCA2 in the DNA-damage response. Curr Biol 19: 524-529.
Zhao GY, Sonoda E, Barber LJ, Oka H, Murakawa Y, Yamada $\mathrm{K}$, Ikura T, Wang X, Kobayashi M, Yamamoto K, et al. 2007. A critical role for the ubiquitin-conjugating enzyme Ubc13 in initiating homologous recombination. Mol Cell 25: 663-675.

Zhong Q, Chen CF, Li S, Chen Y, Wang CC, Xiao J, Chen PL, Sharp ZD, Lee WH. 1999. Association of BRCA1 with the hRad50-hMre11-p95 complex and the DNA damage response. Science 285: 747-750.

Zhou Y, Caron P, Legube G, Paull TT. 2013. Quantitation of DNA double-strand break resection intermediates in human cells. Nucleic Acids Res 42: e19.

Zhu Q, Pao GM, Huynh AM, Suh H, Tonnu N, Nederlof PM, Gage FH, Verma IM. 2011. BRCA1 tumour suppression occurs via heterochromatin-mediated silencing. Nature 477: 179-184.

Zimmermann M, Lottersberger F, Buonomo SB, Sfeir A, de Lange T. 2013. 53BP1 regulates DSB repair using Rif1 to control 5' end resection. Science 339: 700-704. 


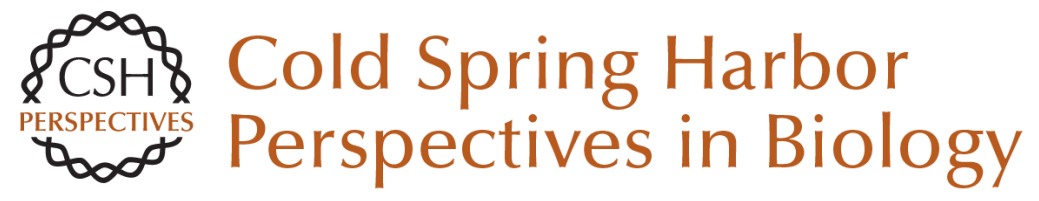

\title{
Homologous Recombination and Human Health: The Roles of BRCA1, BRCA2, and Associated Proteins
}

\author{
Rohit Prakash, Yu Zhang, Weiran Feng and Maria Jasin
}

Cold Spring Harb Perspect Biol 2015; doi: 10.1101/cshperspect.a016600

\section{Subject Collection DNA Recombination}

Meiotic Recombination: The Essence of Heredity Neil Hunter

Regulation of Recombination and Genomic Maintenance Wolf-Dietrich Heyer

Initiation of Meiotic Homologous Recombination: Flexibility, Impact of Histone Modifications, and Chromatin Remodeling Lóránt Székvölgyi, Kunihiro Ohta and Alain Nicolas

Mechanism and Regulation of Meiotic

Recombination Initiation Isabel Lam and Scott Keeney

Homologous Recombination and Human Health: The Roles of BRCA1, BRCA2, and Associated Proteins Rohit Prakash, Yu Zhang, Weiran Feng, et al.

\section{Cell Biology of Mitotic Recombination} Michael Lisby and Rodney Rothstein

DNA-Pairing and Annealing Processes in Homologous Recombination and Homology-Directed Repair Scott W. Morrical
An Overview of the Molecular Mechanisms of

Recombinational DNA Repair

Stephen C. Kowalczykowski

Recombination, Pairing, and Synapsis of Homologs during Meiosis

Denise Zickler and Nancy Kleckner

DNA Strand Exchange and RecA Homologs in

Meiosis

M. Scott Brown and Douglas K. Bishop

Meiosis and Maternal Aging: Insights from

Aneuploid Oocytes and Trisomy Births Mary Herbert, Dimitrios Kalleas, Daniel Cooney, et al.

Mismatch Repair during Homologous and

Homeologous Recombination Maria Spies and Richard Fishel

\section{Mechanisms of Gene Duplication and Amplification Andrew B. Reams and John R. Roth}

The Role of Double-Strand Break Repair Pathways at Functional and Dysfunctional Telomeres Ylli Doksani and Titia de Lange

For additional articles in this collection, see http://cshperspectives.cshlp.org/cgi/collection/

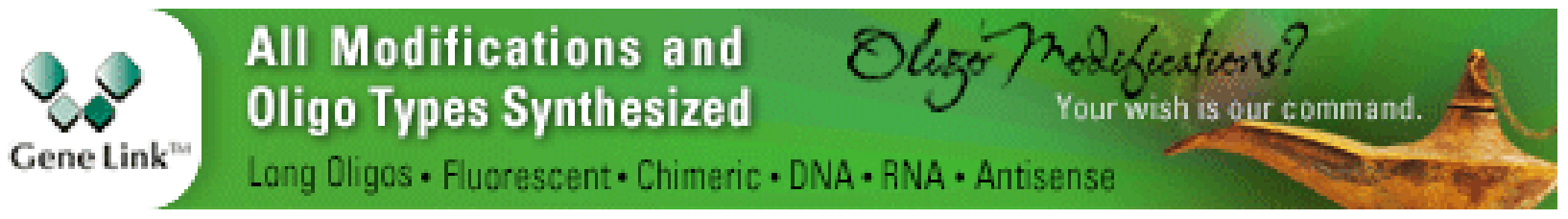




\section{Mediators of Homologous DNA Pairing}

Alex Zelensky, Roland Kanaar and Claire Wyman
Regulation of DNA Pairing in Homologous

Recombination

James M. Daley, William A. Gaines, YoungHo Kwon, et al.

For additional articles in this collection, see http://cshperspectives.cshlp.org/cgi/collection/

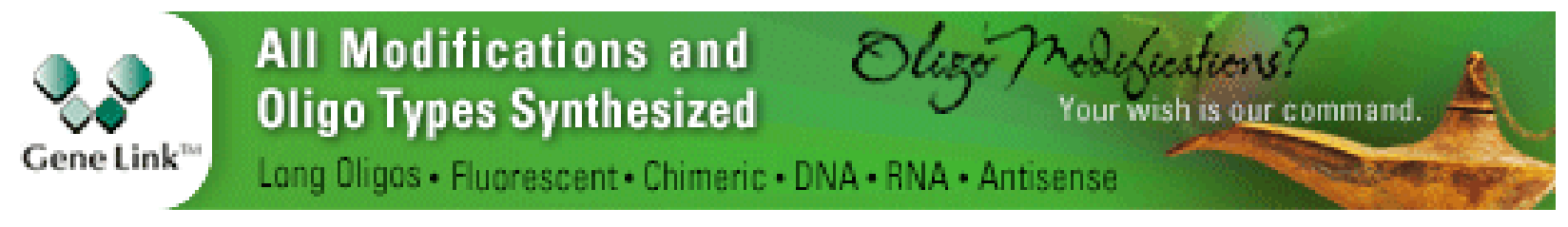

Copyright @ 2015 Cold Spring Harbor Laboratory Press; all rights reserved 